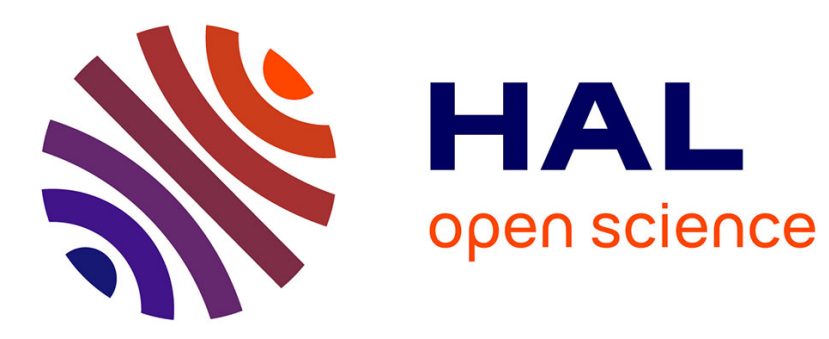

\title{
Polyphased mesozoic rifting from the Atlas to the north-west Africa paleomargin
}

Frederic O Escosa, Rémi Leprêtre, Vincenzo Spina, Oriol Gimeno-Vives, Charlie H Kergaravat, Geoffroy Mohn, Dominique Frizon de Lamotte

\section{- To cite this version:}

Frederic O Escosa, Rémi Leprêtre, Vincenzo Spina, Oriol Gimeno-Vives, Charlie H Kergaravat, et al. Polyphased mesozoic rifting from the Atlas to the north-west Africa paleomargin. Earth-Science Reviews, 2021, 220, pp.103732. 10.1016/j.earscirev.2021.103732 . hal-03518687

\section{HAL Id: hal-03518687 \\ https://hal.science/hal-03518687}

Submitted on 10 Jan 2022

HAL is a multi-disciplinary open access archive for the deposit and dissemination of scientific research documents, whether they are published or not. The documents may come from teaching and research institutions in France or abroad, or from public or private research centers.
L'archive ouverte pluridisciplinaire HAL, est destinée au dépôt et à la diffusion de documents scientifiques de niveau recherche, publiés ou non, émanant des établissements d'enseignement et de recherche français ou étrangers, des laboratoires publics ou privés. 
doi : $\underline{\text { https://doi.org/10.1016/j.earscirev.2021.103732 }}$

\title{
Polyphased mesozoic rifting from the Atlas to the north-west Africa paleomargin
}

Frederic O. Escosa (a,b)*, R. Leprêtre (c), V. Spina (a), O. Gimeno-Vives (c), Ch. Kergaravat (a), G. Mohn (c),

Dominique Frizon de Lamotte (c)

()a Total SA, Centre Scientifique et Technique Jean Féger, Avenue Larribau, 64018 Pau, France

(b) Université de Bourgogne Franche-Comté, Centre des Sciences de la Terre, UMR CNRS 6282 Biogéosciences, 6 Bd Gabriel, 21000 Dijon, France

(c) CY Cergy Paris Université, Département Géosciences et Environnement (GEC), 1 rue Descartes, 95000 Neuville, Oise Cedex, France

* corresponding author : fredescosa@gmail.com

\begin{abstract}
Based on the interpretation of geological maps, seismic reflection and well data complemented with a bibliographic compilation and field work in the Rif, we investigate the factors that control the rift initiation, its development and the formation of oceanic crust in NW Africa. From SE to NW, we examine the Western Sahara Atlas, the Tendrara, the Guercif, and the Rif basins, to establish their geodynamic evolution in relation with the Mesozoic formation of the Central Atlantic and Maghrebian Tethys oceans, respectively. The Triassic extension was diffuse and developed over Lower Carboniferous horst-and-graben structures formed in the NW passive margin of Gondwana and involved in the subsequent late Carboniferous - early Permian Variscan orogenic system; suggesting that, at the onset of the Triassic rifting, the lithosphere was thermally re-equilibrated and replaced by more fertile lithospheric mantle. Afterwards, extension resumed in the Atlas system during middle to late Pliensbachian and finished during Toarcian. In the Rif and Guercif basins, the extension began later, mainly during the Toarcian, climaxing during Middle Jurassic times with the exhumation along low-angle extensional faults of CAMP gabbroic bodies and the final mantle exhumation during Upper Jurassic in the Rif. The study evidences the prominent role of the Variscan structural and thermal inheritance on the subsequent deformation events. Accordingly, the Paleozoic inverted basins and
\end{abstract}


horsts localized the Triassic extension. From that, the opening of the Central Atlantic and Maghrebian Tethys oceans activated, respectively, the SE (Atlas) and NW (Tethys) rifted segments of the weakened continental crust where the Jurassic extension was gradually distributed. This led to the final formation of an oceanic domain in the NW paleomargin of Africa.

\section{Introduction}

The opening of an oceanic domain can be the consequence of a single episode of rifting as observed along the southern margin of the Paleo-Tethys giving birth to the Neo-Tethys Ocean during the Permian (Stampfli et al., 1991; Ricou, 1994; Korsch et al., 2009). It can also result from the superimposition of several rifting events separated by quiescent periods finally leading to fully rifted continental margins. This, for instance, is the case of the failed late Carboniferous-Permian rift over the Variscan Orogen (upper Carboniferous to early Permian) and the further development, in this weakened zone, of the Triassic-Lower Jurassic Central Atlantic rift system (Burg et al., 1994; Oftedal et al., 2005; Redfern et al., 2010).

The specific features and the tectonic evolution of a rift system are mainly controlled by the rate of extension, the presence of inherited structures, and the rheology of the stretched lithosphere that varies according to its composition and thermal state (Steckler and ten Brink, 1986; Kusznir et al., 1987; Buck, 1991; Stampfli et al., 1991; Hopper and Buck, 1996; Brun, 1999; van Wijk and Cloetingh, 2002; Gueydan and Précigout, 2014). In this regard, the weakening of the lithosphere and ultimate breakup is linked to two main elements: (1) the horizontal tectonic stress acting at the boundaries of the initial rift system, which are mostly related to the so-called "slab pull" mechanism (McKenzie, 1978; LithgowBertelloni and Richards, 1998); and (2) the heat source related to the presence of a mantle plume responsible of thermal weakening at the base of the lithosphere (Burke and Dewey, 1973). These two elements are not self-excluding, so that they may occur in combination through the rift history (Ziegler and Cloetingh, 2004; Huismans et al., 2001; Merle, 2011). In addition to these constrains, the initial set-up of the lithosphere (i.e. the structural inheritance represented, for example, by collapsed orogens, older rift systems or lithospheric-scale faults) also controls the localization and subsequent development of a rift system (Frizon de Lamotte et al., 2015; Duretz et al., 2016; Petri et al., 2019).

Extension leading to the opening of an oceanic domain can affect a wide zone of the lithosphere forming a rift system (Şengör and Burke, 1978; Buck, 1991; Khain, 1992; Ziegler, 1992; Brun, 1999), with the subsequent development of "rim basins" bordering the spreading center. A key controlling factor on the width of a rift system, besides the ones described above, is also the modalities of rheological coupling between the layered crust and subcontinental mantle (Gueydan et al., 2008). At 
the beginning of rifting, the deformation is decoupled and distributed over a large region, and as rifting evolves in time and space, it becomes progressively coupled and localized on the site of the future oceanic domain. This evolution leads to a final configuration in which the rift basins are older at the periphery of the system (e.g. "rim basins") and younger towards the spreading axis. In this regard, numerical and physical scaled models show that the development of a wide rift zone is favored by the presence of a thick and hot crust (e.g. a young mountain belt), deformed over a long period of time at low strain rates (Buck, 1991; Brun, 1999; van Wijk and Cloetingh, 2002).

In cases of polyrifted margins (i.e. when successive rifting episodes separated by sag "quiet" periods occur in the same region, like for example along the Atlantic margin), the locus of rifting may change, leading to the formation of extensional basins distributed in time and space along the rift system. It is, for instance, the case of the Atlantic- Tethys triple junction where several episodes of rifting occurred before the accretion of the oceanic crust and the drifting stage (Favre and Stampfli, 1992; Frizon de Lamotte et al., 2011; Fernandez, 2019; Gimeno-Vives et al., 2019). Because of this polyphased history of rifting, the Tethys in the Maghreb region in NW Africa was fringed to the south by a wide strip of intra-continental rim basins forming the Atlas system separated by less-deformed paleo-highs (e.g. Frizon de Lamotte et al., 2000, 2008, and Frizon de Lamotte et al., 2011).

This paper analyzes a series of poorly inverted rim basins in NW Africa (Fig. 1a) in order to establish their tectonic and geodynamic evolution in relation with the Mesozoic development of the Central Atlantic and Maghrebian Tethys, respectively. From southeast to northwest, the rim basins incorporated into the analysis are (Fig. 1b): the Western Sahara Atlas, the Tendrara Basin, the Guercif Basin/Middle Atlas, and finally the Rif Basin in which the former margin of the Maghrebian Tethys was recognized (i.e., Favre, 1992; Gimeno-Vives et al., 2019; Gimeno-Vives et al., 2020a; Michard et al., 2020). Based on geological maps, vintage subsurface data, well data and the available literature, this study aims to evaluate the structural styles and the polyphased rifting history of extensional rim basins in NW Africa at the Central Atlantic/Maghrebian Tethys junction and to describe their evolution in the regional frame of the NW African paleomargin formation. Then, we will discuss the role of inheritance on the nucleation of the successive rift systems and finally factors that control a differently distributed inversion affecting the Mesozoic rim basins during the Alpine cycle.

\section{Geological setting: the successive rifting episodes shaping NW Africa}

The investigated areas are in the NW corner of Africa (Fig. 1b) where two main E to NE-trending orogenic systems developed by the Late Cretaceous as a response to the convergence of the African and Eurasian plates (Durand-Delga and Fontboté, 1980). The resulting orogenic belts are the Rif-Tell to the north and the Atlas system to the south (Fig. 1b). 

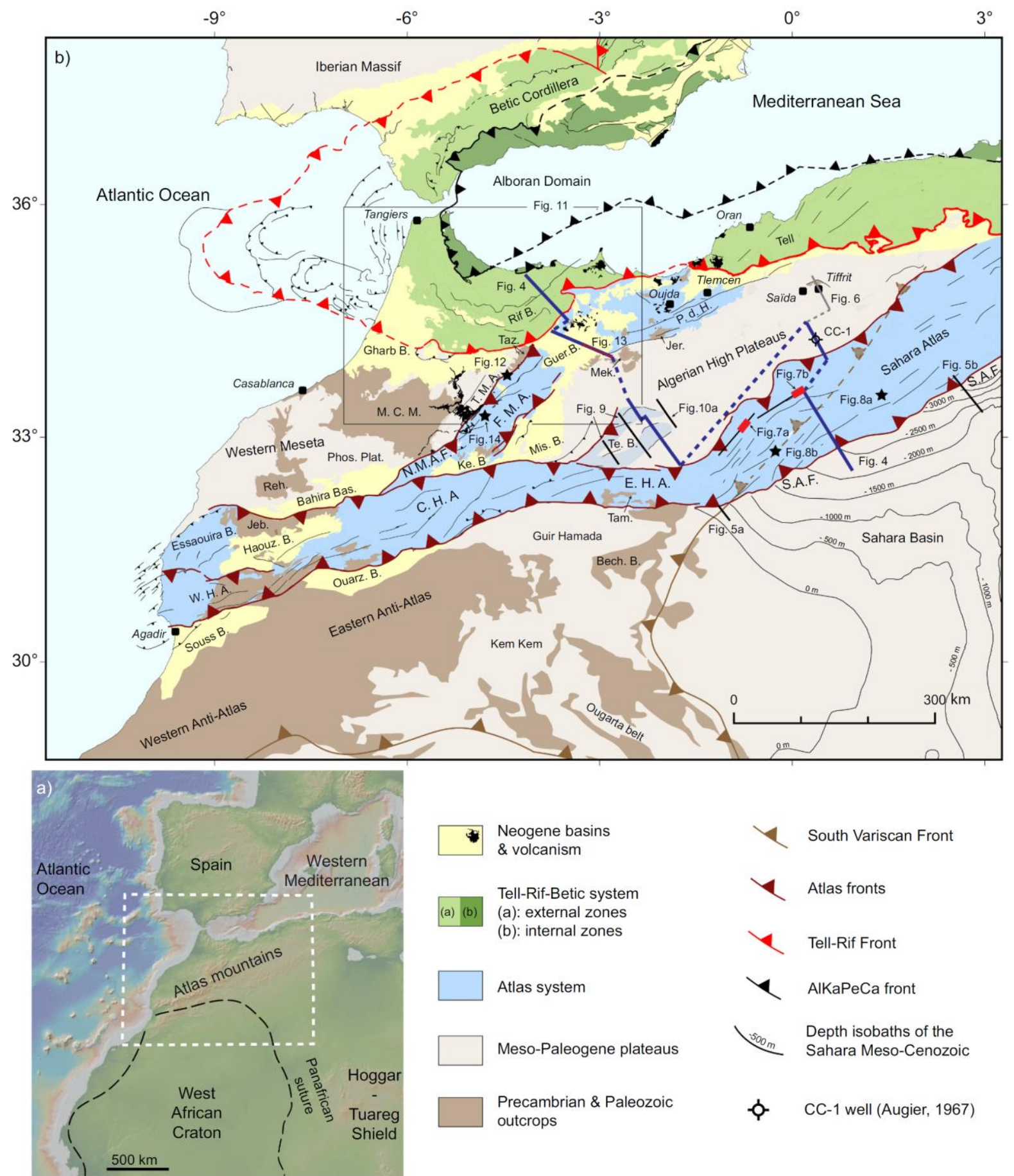

Neogene basins $\&$ volcanism

Tell-Rif-Betic system

(a): external zones

(b): internal zones

Atlas system

Meso-Paleogene plateaus

Precambrian \& Paleozoic outcrops

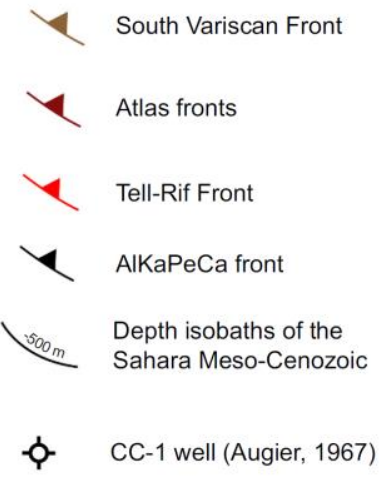

- $\mathbf{-} \quad$ CC-1 well (Augier, 1967)

Fig. 1. a) Relief map of the western Mediterranean and NW Africa; b) Structural map of NW Africa depicting the main orogenic systems. Note the location and names of the areas and structures cited along the text. Modified from Frizon de Lamotte et al. (2011). Coordinates are in degrees in World Geodetic System 84. Abbreviations: P. d. H: “Pays des Horsts”; Jer.: Jerada Massif; Taz.: Tazzeka Massif; Mek.: Mekkam Massif; T. M. A.: “tabular” Middle Atlas; F. M. A.: “folded” Middle Atlas; Mis. B.: Missour Basin; Te. B.: Tendrara Basin; N. M. A. F.: North Middle Atlas Fault; M. C. M.: Moroccan Central Massif; Ke. B.: Kerrouchene Basin; Phos. Plat. Phosphates Plateaus; Reh.: Rehamna Massif; Jeb.: Jebilet Massif; W. H. A.: Western High Altas; C. H. A.: Central High Atlas; E. H. A.: Eastern High Altas; S. A. F.: South Atlas Front; Tam.: Tamlelt Massif; Bech. B.: Bechar Basin. 
The Rif in Morocco and Tell in Algeria and Tunisia, formed in response to the closure of the Maghrebian Tethys and the inversion of the associated paleomargins (see review in Leprêtre et al., 2018a). The Atlas system comprises a set of intracontinental doubly-verging fold-and-thrust belts (i.e. High Atlas, Middle Atlas, Sahara Atlas, Aurès and Tunisian Atlas) derived from the inversion of several rim basins associated with the development of the Atlantic and Tethys oceanic domains during the Mesozoic (e.g. Frizon de Lamotte et al., 2000; Frizon de Lamotte et al., 2009; Khomsi et al., 2006; Khomsi et al., 2009; Teixell et al., 2003). South of the High Atlas, the Anti-Atlas and Ougarta constitute older fold-and-thrust belts developed during the Late Paleozoic (Variscan Orogeny) and partially covered by a thin MesoCenozoic cover (Burkhard et al., 2006; Michard et al., 2008; Fig. 1b). East of the studied area, the Sahara Atlas is bounded to the southeast by the Sahara Basin (Fig. 1b), a flat region consisting of a pile of Paleozoic and Meso- Cenozoic sedimentary rocks affected by low magnitude deformation during the Phanerozoic times (Boote et al., 1998; Craig et al., 2008; Frizon de Lamotte et al., 2013).

Rifting in NW Africa developed during successive stages of extension since the Late Paleozoic through Mesozoic times (Fig. 2). The first episode of rifting in the Moroccan Meseta, Atlas and the Anti-Atlas domains was responsible for the development of Paleozoic basins in two phases: a first CambrianOrdovician extensional phase accompanied by continental magmatism (Hollard et al., 1982; El Hassani, 1994; Soulaimani et al., 2004); and a second one, Middle/Late Devonian to earlyCarboniferous time interval, responsible for the development of a "platform and basin topography" (sensu Wendt, 1985). This second extensional phase was mainly controlled by NNE-SSW and transverse E-W to ENE-WSW oriented basement faults that contributed to the gradual foundering and disintegration of the NW passive margin of Gondwana (Wendt, 1985; El Kamel and El Hassani, 2006; Wendt et al., 2006; Simancas et al., 2009; Eschard et al., 2010; Frizon de Lamotte et al., 2013). The subsequent late Carboniferous-early Permian Variscan Orogeny developed over this area by the re-activation of the major structural trends inherited from the previous deformation events (Burkhard et al., 2006; Wernert et al., 2016; Delchini et al., 2018). This resulted in the formation of the Moroccan Variscides, comprising the Moroccan Mesetas (i.e., both the Western Meseta and the Algerian High Plateaus on Fig. 1b) and the Anti-Atlas (Hoepffner et al., 2006; Michard et al., 2008; Michard et al., 2010). A third episode of rifting recorded in the region is related to an intermediate phase between the two main contractional stages of the Variscan orogeny during the uppermost Carboniferous-early Permian (Chopin et al., 2014; Delchini et al., 2018). This is possibly linked to partial orogenic collapse and/or globally, by thermal insulation of the Pangea continental aggregation and subsequent large-scale melting localized along preexisting lithospheric weaknesses in different geological contexts (Frizon de Lamotte et al., 2015). Nevertheless, in NW Africa they constituted aborted rift basins scattered over the dismantling orogenic belt (Dercourt et al., 2000). 


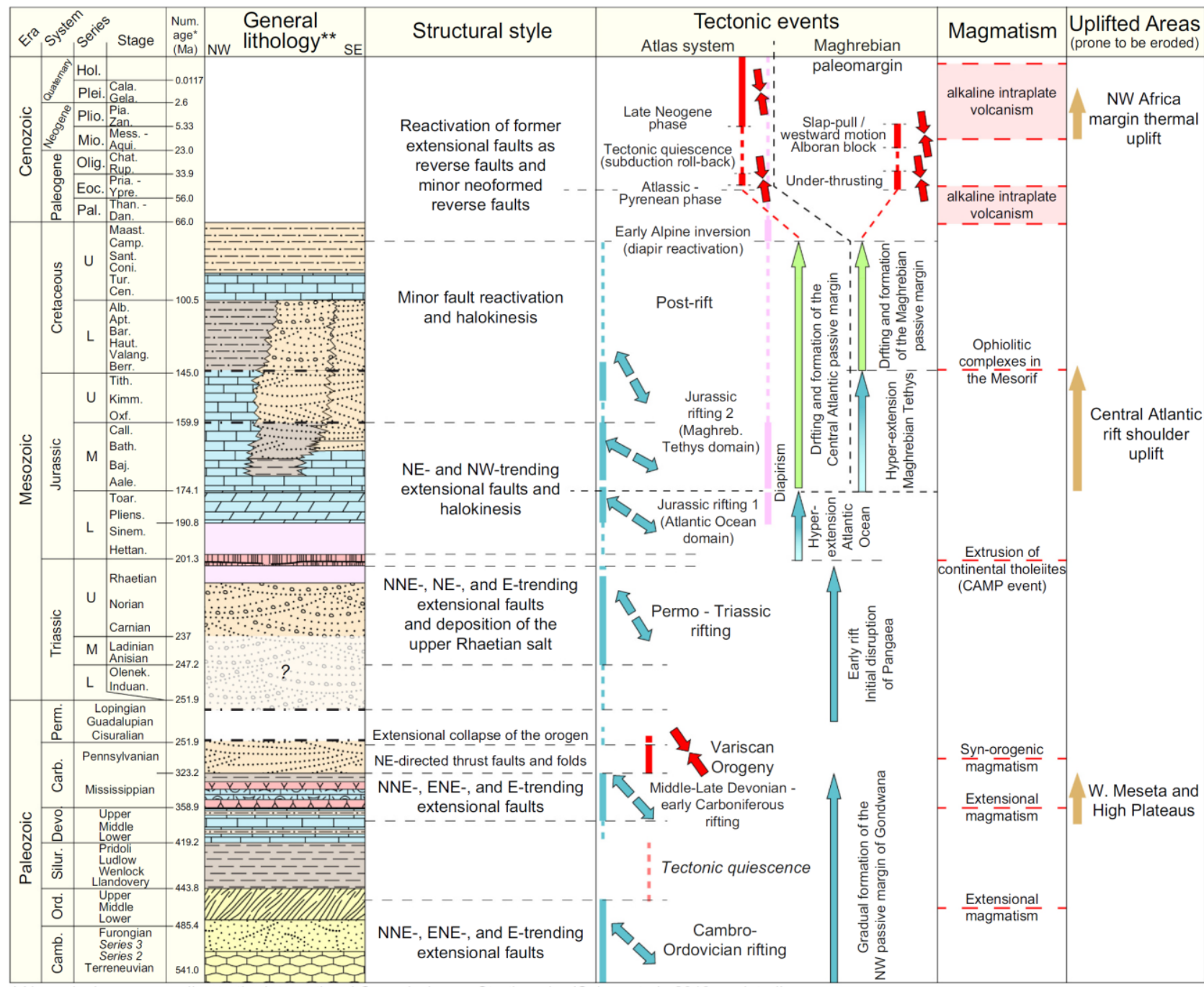

${ }^{*}$ Numerical ages according to the International Commission on Stratigraphy (Cohen et al., 2013, updated).

${ }^{* \star}$ Lithological variations in the NW Africa margin from the Rift Basin (NW) to the western Sahara Atlas (SE)

Color code lithology
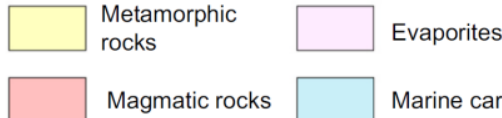

Evaporites

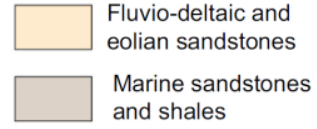

Lithology

$\begin{array}{llll} & \text { Quartzite } & \text { Carbonates } \\ & & \\ & \end{array}$

\begin{tabular}{|c|c|}
\hline 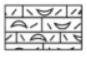 & $\begin{array}{l}\text { Bioclastic } \\
\text { carbonates }\end{array}$ \\
\hline & Sandstones \\
\hline 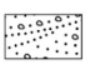 & $\begin{array}{l}\text { Conglomerates and } \\
\text { sandstones }\end{array}$ \\
\hline
\end{tabular}

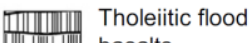

basalts

Dolomites

Fig. 2. Tectonostratigraphic chart of NW Africa depicting a general lithology, the main tectonic events and related structural styles and associated magmatism from the NW Africa margin to the western Sahara Atlas. 
The progressive opening of the Central Atlantic Ocean (Stampfli, 2000; Ellouz et al., 2003; Davison, 2005; Leleu et al., 2016), led to the formation of a new phase of rifting affecting the Pangea continent in the Middle to Late Triassic (Fig. 3). During this stage, rifting propagated north-eastward from the Central Atlantic towards the Tethys domain along the northwestern African paleomargin. This rifting phase was controlled by NNE- to NE-trending extensional faults in the Atlantic margin of Morocco (e.g. Essaouira Basin or Western High Atlas), but to the northeast was controlled by NE- to E-trending faults in the High Atlas, Sahara Atlas, Middle Atlas, "Pays des Horsts" and up to the Tunisian Atlas (Fernandez, 2019).

The end of the Triassic rifting is marked over the Atlantic and Tethys margins of Morocco by the flooding of continental tholeiites, dated at $200 \pm 1 \mathrm{Ma}$ (Olsen et al., 2003; Knight et al., 2004; Marzoli et al., 2004; Panfili et al., 2019; Gimeno-Vives et al., 2019; Haissen et al., 2021). These basaltic extrusions, forming together the Central Atlantic Magmatic Province (see Fig. 3 for the distribution and limits of the CAMP event in NW Africa), mark the boundary between the Triassic and Jurassic and predate the drifting in the northern central Atlantic segment (Marzoli et al., 1999; Marzoli et al., 2004; Knight et al., 2004; Verati et al., 2007; Nomade et al., 2007). Thereby, spreading of the oceanic crust began during earliest Jurassic in the southern central Atlantic (i.e., the oceanic segment located south of Iberia; Favre and Stampfli, 1992; Stampfli et al., 2001; Sahabi et al., 2004; Stampfli and Borel, 2004; Labails et al., 2010; Kneller et al., 2012) and propagated northeastward to the Tethys realm (Frizon de Lamotte et al., 2011). The Middle to Late Jurassic phase of extension combined with the coeval sedimentation triggered salt migration and the development of diapiric structures made up of Triassic evaporites over the Central High Atlas, Sahara Atlas, Tunisian Atlas, Rif and Tell margins (Saura et al., 2013; Troudi et al., 2017; Teixell et al., 2017; Gimeno-Vives et al., 2019). This process represented the final fragmentation of Pangaea and led ultimately to the opening of the Maghrebian Tethys during the Middle to Upper Jurassic (Favre and Stampfli, 1992; Bracène and Frizon de Lamotte, 2002; GimenoVives et al., 2019).

South of the Maghrebian Tethys, the Atlas system partly bounds the Western Meseta and surrounds the Algerian High Plateaus. Both areas comprise several Paleozoic massifs that remained as poorly subsiding basement highs during the Mesozoic (e.g. in Western Meseta: Ghorbal et al., 2008; Saddiqi et al., 2009). South of the Western Meseta, the Atlas system can be subdivided into an Atlantic domain to the west and southwest (including the Western High Atlas; Fig. 1b) and an eastern/ northeastern domain showing Tethys affinities (i.e. Central High Atlas, Middle Atlas and northeastern extension into the "Pays des Horsts", Sahara Atlas, Aurès (Algeria) and Tunisian Atlas; Frizon de Lamotte et al., 2008; Fig. 1b). In the Western High Atlas, extension occurred mostly during late Permian-Triassic times, controlled by NNE-trending extensional faults, and thus dominated by the development of the Central 
Atlantic Ocean (Hafid et al., 2006). Towards the eastern/northeastern part of the Atlas system instead (i.e. Middle Atlas, Guercif Basin, Sahara Atlas, Aurès Basin and Tunisian Atlas), major extension occurred later. It is controlled by NE-trending extensional faults and is rather associated to the development of the Maghrebian Tethys during Jurassic times. However, at the center of the Atlas system (i.e. Central High Atlas, Tendrara Basin), the developing basins where influenced by both extensional phases due to the progressive northeastwards opening of the Tethys domain.

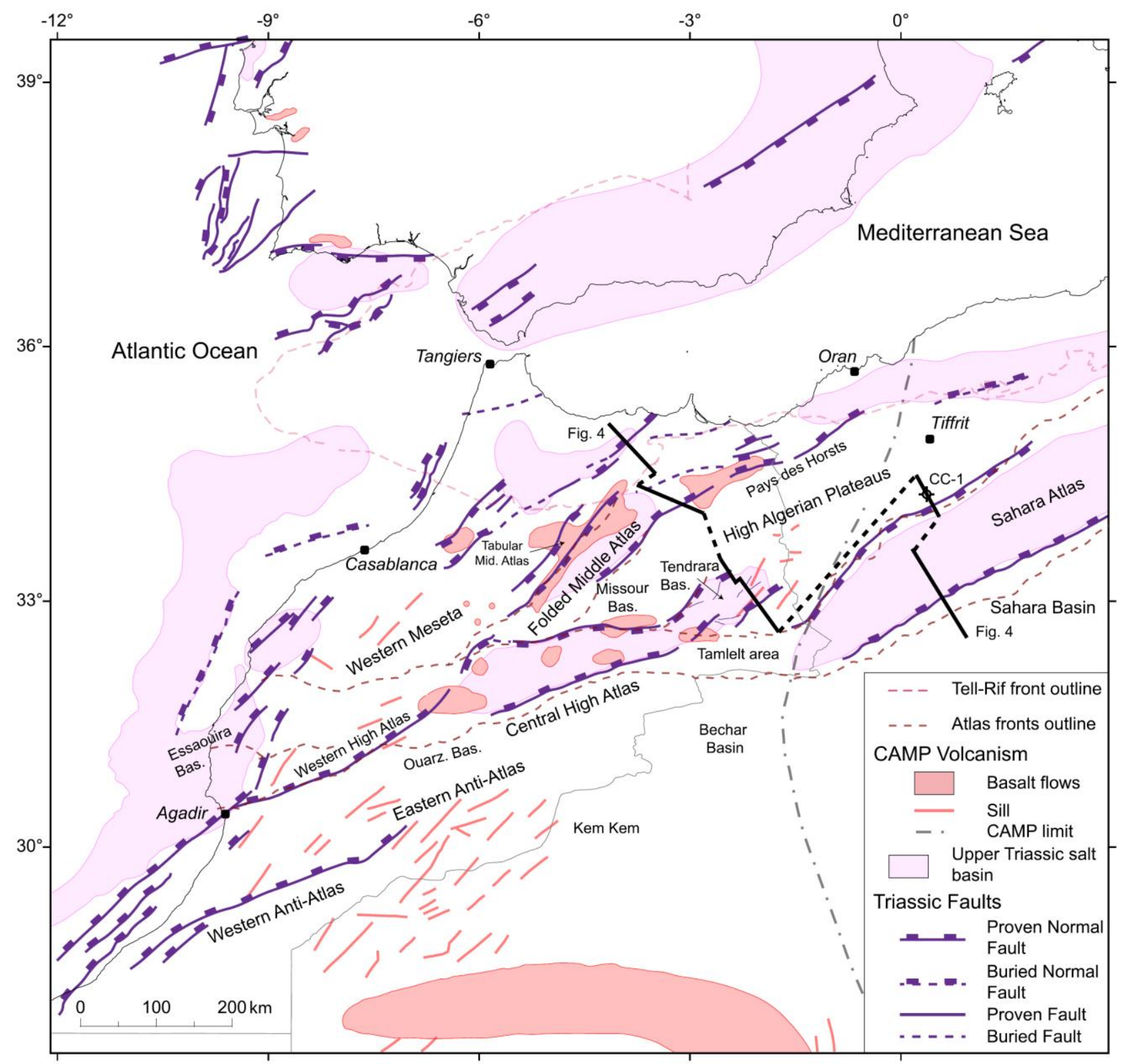

Fig. 3. Upper Triassic tectonic map of northwestern Africa and southern Iberia depicting the locations of the main basins and bounding faults as well as the CAMP volcanism. Note how the CAMP sills are emplaced following the main trends of the extensional faults. Coordinates are in degrees in World Geodetic System 84. 


\section{General lithostratigraphy of NW Africa}

The stratigraphy of the studied basins can be grouped into four main sedimentary groups according to the geodynamic events that affected NW Africa during Paleozoic and Mesozoic times and described in the previous section (Fig. 2).

1. A Paleozoic succession that from bottom to top is composed of: Cambrian-Ordovician marbles, quartzites and metapelites; Silurian black shales; Devonian shallow marine carbonates and sandy shales; early Carboniferous shales and bioclastic marine carbonates interbedded with andesitic and rhyolitic tuffas and ashes; and a late Carboniferous-lowermost Permian assemblage of fluviatile and deltaic sediments (Medioni, 1980; Hoepffner, 1981, 1987; Piqué and Michard, 1989). The Cambrian to early Carboniferous succession was deposited along the passive margin of Gondwana (Wendt, 1985; Simancas et al., 2009; Eschard et al., 2010; Frizon de Lamotte et al., 2013). By contrast, the late Carboniferous continental sediments are syn-orogenic and deposited during the inversion of the previous extensional basins during the Variscan Orogeny (Hoepffner et al., 2006; Saber et al., 2007; Graham and Sevastopulo, 2007)

2. An uppermost Permian-Triassic unit lying unconformable over the Paleozoic succession (Saber et al., 2007; Benaouiss et al., 2011). It is represented by: a lower Carnian-Norian coarse-grain fluvial unit (e. g. "TAGI" reservoir in Algeria and eastern Morocco); and an upper Rhaetian finer-grained mudflat to evaporitic unit (e.g. Keuper evaporites; Beauchamp, 1988; Leleu and Hartley, 2010; Ortí et al., 2017). These deposits are syn- to post-rift by reference to the Triassic extensional phase (Fig. 3), which are sealed by the tholeiitic flood basalts of the CAMP (Bertrand, 1991; Youbi et al., 2003; Hafid, 2000). The Triassic evaporitic unit, here and after referred as lower salt, constitutes a regional décollement level activated several times during the subsequent deformation affecting NW Africa.

3. Overlying the previous group, a Lower-Middle Jurassic succession displays major thickness variations over the studied rim basins. It is composed of: a basal evaporitic unit, HettangianSinemurian in age, capped by anhydrites and dolomites (here and after referred as the upper salt unit); a middle dolomitic unit, Pliensbachian-Toarcian in age, and an upper limestone unit Middle Jurassic in age (Du Dresnay, 1987; Zizi, 2002; El Hammichi et al., 2002; Ait Addi, 2006). These are syn-rift deposits by reference to the Lower-Middle Jurassic rifting associated to the development of the Maghrebian Tethys (Favre et al., 1991; Gimeno-Vives et al., 2019; Gimeno-Vives et al., 2020a; Michard et al., 2020). In addition, salt migration triggered by thick-skinned extension was also important on contributing for the thickness variations observed in the upper carbonate unit (Saura et al., 2013; Moragas et al., 2016). It is worth noting that the above described Paleozoic to Norian succession constitutes the subsalt unit in relation to the lower and upper salt, and that the overlying successions constitute the suprasalt 
units. So, during the Mesozoicextensional events, the subsalt rocks were mechanically coupled and thus behaved as basement.

Finally, the Upper Jurassic to Lower Cretaceous succession can be attributed to a post-rift phase in relation to the Lower-Middle Jurassic rifting. This period is characterized by a differentiation of the sedimentary environments over NW Africa (Fabre, 2005). There is no deposition on the western sector (Western High Atlas and Moroccan Meseta), clastic sedimentation in the center (Central High Atlas), and carbonate sedimentation in the eastern Atlas system (Vially et al., 1994; Elmi, 1996). By the Upper Cretaceous, the sedimentation becomes homogenous at scale of the whole Northwest African margin (Haddoumi et al., 2008).

\section{Structure and evolution description of the Atlas rim basins and the NW-Africa paleomargin}

The following subsections are devoted to describe the structure and stratigraphy of the investigated areas in NW Africa from SE to the NW. Fig. 4 shows a SSE-trending composite regional cross-section that illustrates the style of deformation for the Mesozoic basins. The interpretation in depth of the seismic data was constrained by horizon tops from well data. The geological cross-sections were designed perpendicularly to the main structural trends. However, in places where subsurface data were not available, the construction of the cross-sections was complemented using a compilation of geological maps, published scientific works and field observations

\subsection{The Sahara Atlas}

The Sahara Atlas represents the Algerian eastern continuity of the Eastern High Atlas, with a change of strike from an E-W to a NE-SW orientation (Fig. 1b). The surface geology is known from a set of geological maps (Galmier, 1972a, 1972b) and fieldworks (Bassoulet, 1973; Kazi-Tani, 1986; Mekahli, 1998; Aït Ouali, 1991; Kacemi, 2013). The subsurface data is partly released within few studies but shows a poorly dense network over the area (Kazi-Tani, 1986; Vially et al., 1994; Bracène et al., 1998; Bracène, 2002; Bracène and Frizon de Lamotte, 2002). Only few exploratory wells constraint the geology along the northern and the southern fronts of the Sahara Atlas, where they have generally not reached the basement, nor the Triassic series (see ref. above). Overall, based on the interpretation of the available data, previous authors agree with the control of the sedimentation within NE-SW oriented grabens delimited by thick-skinned extensional faults (Vially et al., 1994; Yelles-Chaouche et al., 2001; Bracène and Frizon de Lamotte, 2002). In terms of structural segmentation, the Sahara Atlas can be sub-divided into the Pre-Atlas to the north and the Atlas Trough to the south (Fig. 4). The latter represents the main depocenter separated from the Pre-Atlas by a structural high developed during 


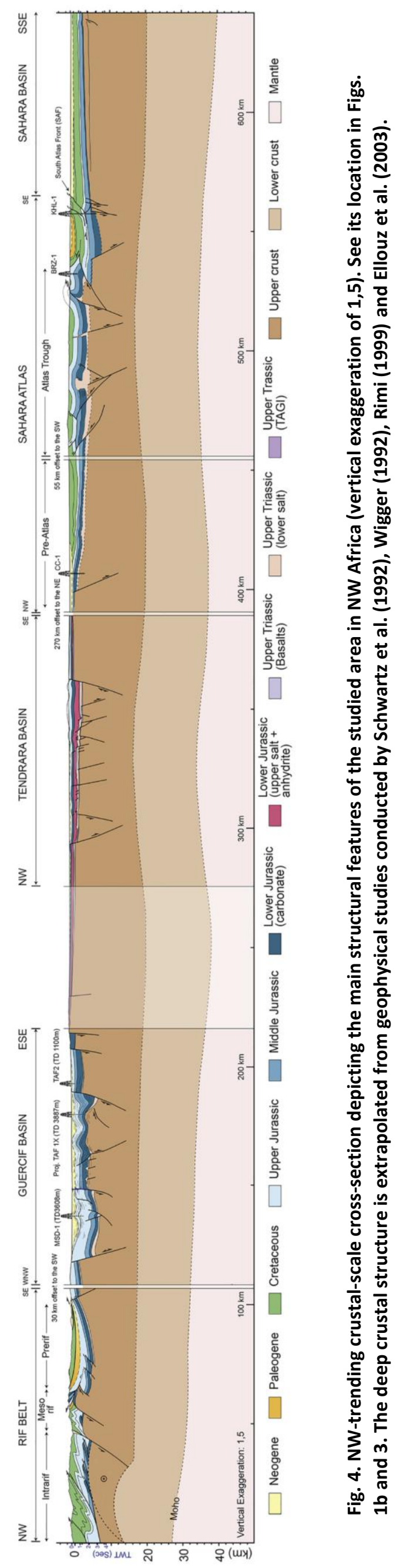


the Early Jurassic (Yelles-Chaouche et al., 2001). In continuity with the Moroccan High Atlas, the Sahara Atlas also constitutes an inverted Mesozoic basin during the Cenozoic (Frizon de Lamotte et al., 2000; Bracène and Frizon de Lamotte, 2002 and references therein).

\subsubsection{Paleozoic inheritance}

No data are available concerning the Paleozoic basement of the Mesozoic Atlas Trough. However, some indirect information regarding the Paleozoic basement can be derived from the southern fringing Sahara Basin and from the Algerian High Plateaus that lie north of the Pre-Atlas (Fig. 1b). The Sahara Basin is deformed along the so-called South Atlas Front (SAF; Figs. 1b and 4). South of the SAF, along the southern part of the Fig. 4 cross-section, the Paleozoic strata are well-imaged in the seismic data showing a simple "layer cake" geometry with sub-parallel reflectors and low-angle unconformities (Fig. 5). North of the Atlas Trough and below the Triassic series, the poor resolution of the seismic data does not allow to properly interpret the Paleozoic structure (Vially et al., 1994). Nevertheless, indirect evidences can beextracted from well data (e.g. CC-1 well) and the outcrops of the Tifrit- Saïda area (Fig. 6). Here, the Paleozoic strata are deformed by thrust faults developed during the Variscan Orogeny and intruded by syn-orogenic magmatic bodies (circa. $298 \mathrm{Ma}$, in Remaci-Benaouda, 2005). In between, below the Pre-Atlas and the Atlas through, the Variscan frontal thrust might be located (Fig. 1b) as already suggested in Frizon de Lamotte et al., 2011 (their Fig. 10). Consequently, the Western Sahara Atlas likely samples the Variscan Front re-worked during the subsequent Mesozoic rifting events, and thus localizing the ensuing deformations.

\subsubsection{Mesozoic rifting}

Seismic imaging and drilling records point out that the Mesozoic rifting started during the Late Triassic (Yelles-Chaouche et al., 2001). Extension was mainly controlled by NE-SW to ENE-WSW oriented thickskinned extensional faults with maximum throws located along the northern part of the Sahara Atlas (Bassoulet, 1973; Kazi-Tani, 1986; Yelles-Chaouche et al., 2001; Bracène, 2002; Bracène and Frizon de Lamotte, 2002). The major thick-skinned faults were relayed by WNW-trending transverse faults compartmentalizing the area in different sub-basins. These narrow and fault bounded basins were infilled by siliciclastic sediments (Triassic in age) overlain by Late Triassic evaporites (Yelles-Chaouche et al., 2001). On top of the evaporites, a Rhaetian-Hettangian dolomitic level (Bassoulet, 1973) capped the Late Triassic (e.g. see EBD-1 well in Bracène, 2002). 

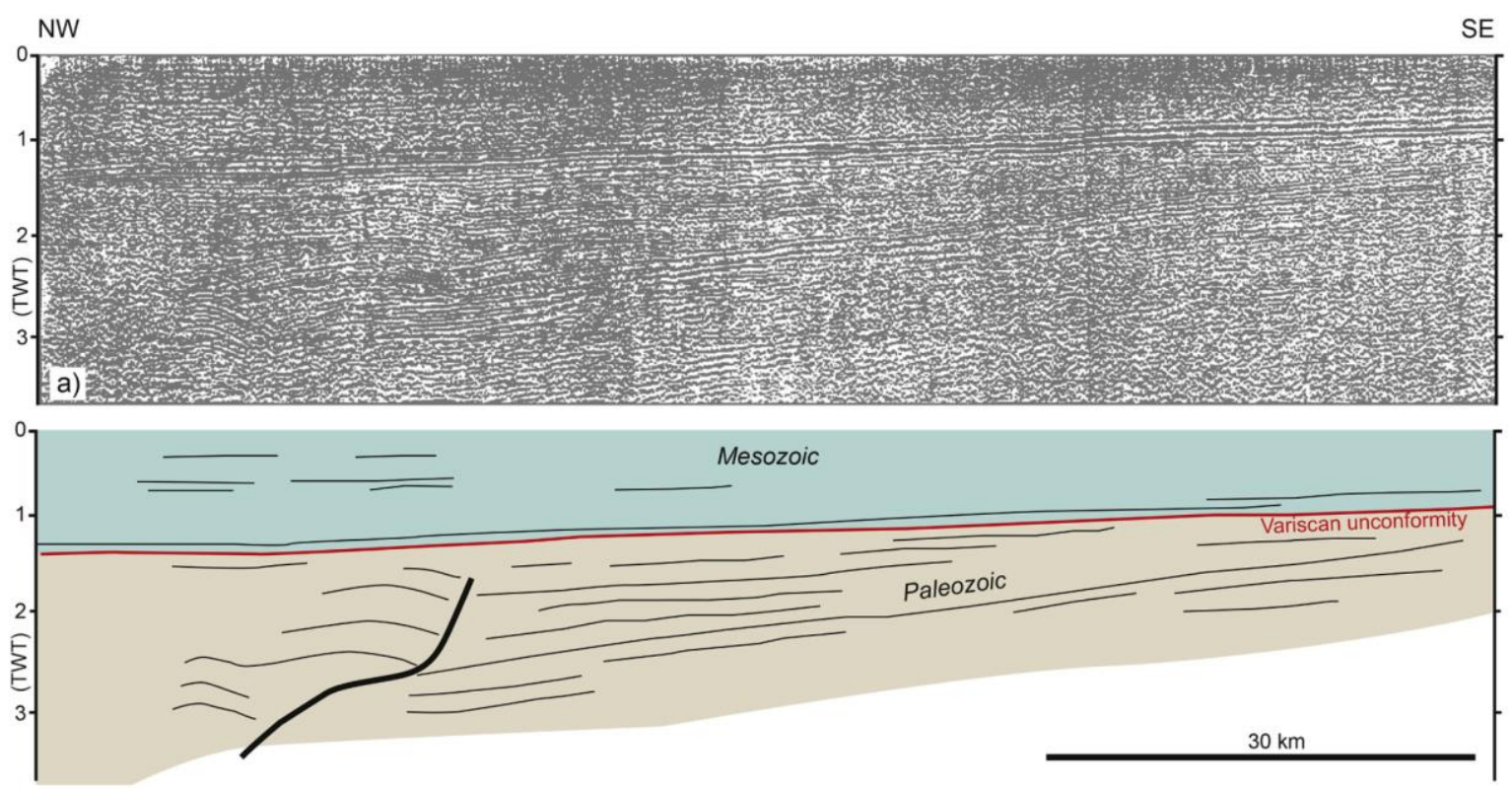

NW

SE
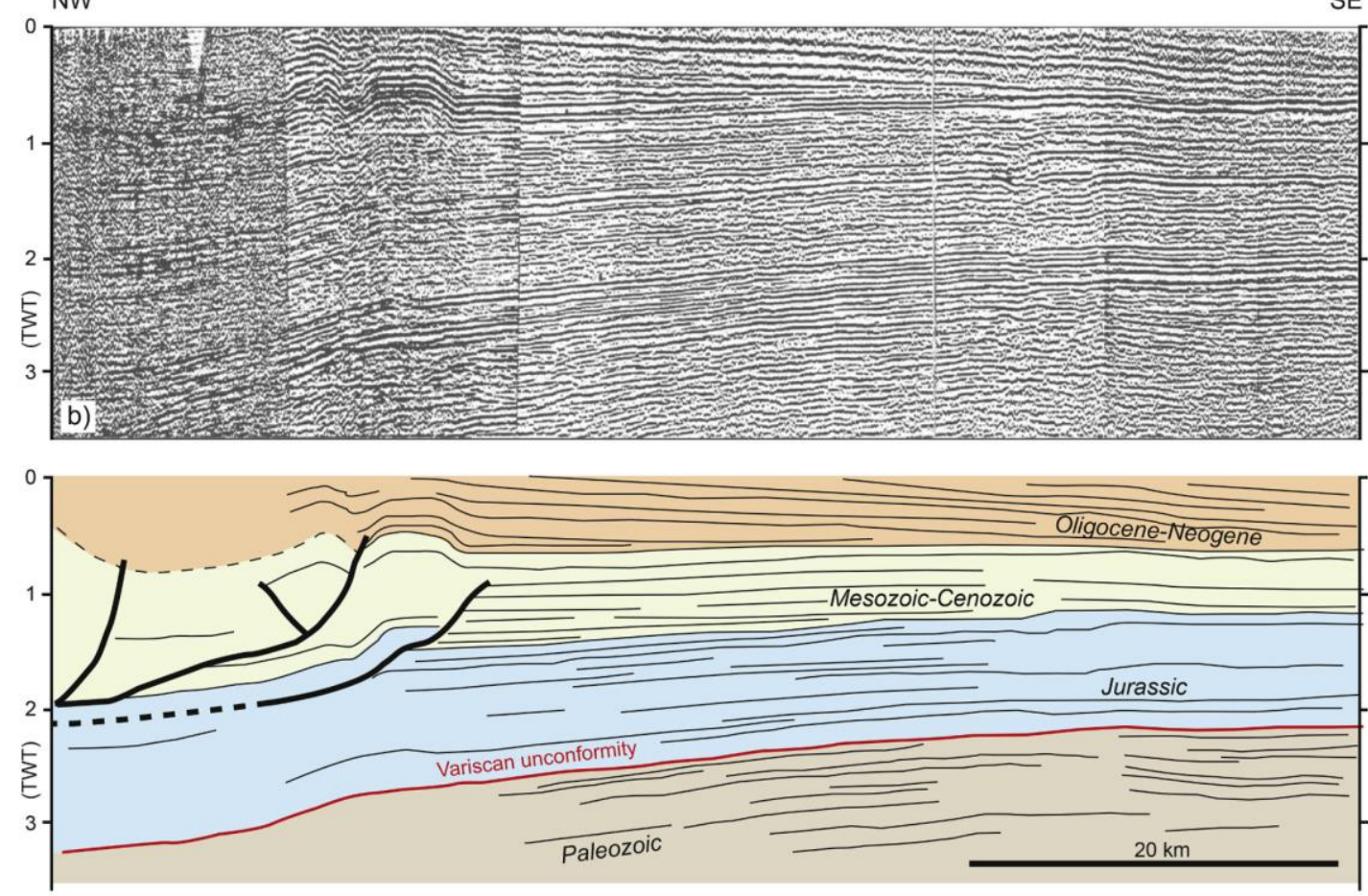

Fig. 5. Interpreted seismic reflection profiles a) and b), located in the Saharan Atlas (see Fig. 1b). Modified from Bracène (2002) and Bracène and Frizon de Lamotte (2002).

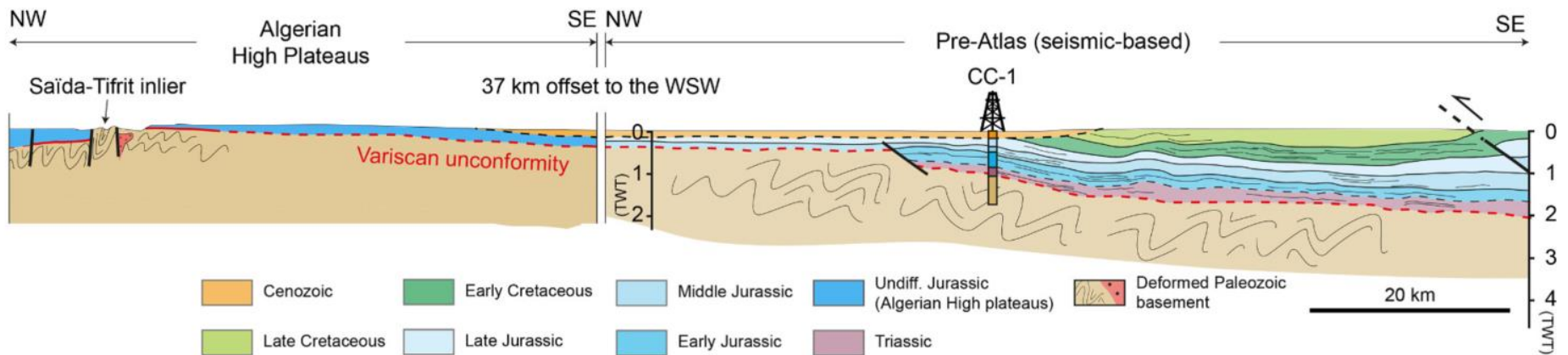

Fig. 6. Seismic-based geological section across the CC-1 well and the Saïda/Tifrit area linking the Pre-Atlas and the High Algerian Plateaus (see location in Fig. 1b). 
Along the southern frontal part of the fold-and-thrust belt, the Triassic evaporites crop out within diapirs piercing through the overburden in the core of anticlines (e.g. Azil and Aït Ouali, 2017). Also, subsurface data from the northern frontal part of the belt show diapir growth related structures (Fig. 7a and b). In these diapiric outcrops, there are pieces of Rhaetian-Hettangian dolomites and CAMP basalts acting as stringers folded and embedded with varicolored clays and evaporites (Chabou et al., 2010; Meddah et al., 2007; Meddah et al., 2017). Therefore, the Triassic evaporites were mobilized during the subsequent rifting phase, a process that makes difficult the reconstruction of their original thickness and the exact timing of the Triassic extension.

A second phase of rifting promoted a rapid deepening of the basin and a change in the sedimentation to open marine with the deposition of the Toarcian-early Bathonian limestones on top of the shallowwater Rhaetian-Hettangian dolomites (Aït Ouali, 1991; Mekahli, 1998; Elmi et al., 1998; YellesChaouche et al., 2001). A clear change in the sedimentation from open-marine conditions to a shallowmarine environment occurred at the end of the Bathonian, and the generated space was fed from the west by an important clastic sedimentary system ("grès des Ksour Fm."; Bassoulet, 1973; Delfaud, 1974 and Delfaud, 1986; Ait Ouali, 1991; Elmi, 1996). This one derived from the erosion of the uplifting footwall blocks of the newly formed Central Atlantic rift shoulder (Lepr^etre et al., 2015).

The structural style of the Toarcian-Bajocian/Bathonian rifting phase has been described in few studies (Vially et al., 1994; Yelles- Chaouche et al., 2001). The authors depicted a general deepening of the basin towards the south and the development of a set of NE-SW oriented extensional faults (Vially et al., 1994; Yelles-Chaouche et al., 2001). In the northern part of the basin within the less-subsiding PreAtlas, the basement extensional faults offset the Jurassic strata (Fig. 6). On the other hand, towards the Atlas Trough (Fig. 4), there is a structural decoupling between the overburden, affected by suprasalt faults soled into the Triassic salt, and the underling subsalt strata which are deformed by thick-skinned extensional faults. The movement along these basement faults and the subsequent salt mobilization controlled the variations of the thickness of the Early and Middle Jurassic strata in a similar way than in the Central High Atlas (Saura et al., 2013).

By Bathonian onwards, subsidence was still important with the development of deltaic systems up to the Albian (Bassoulet, 1973; Delfaud, 1986). However, no rifting events have been identified after the Middle Jurassic, but halokinetic-related deformation is likely, even though they are not properly described in the Western Sahara Atlas. Only good evidences of salt mobilization are observed in the Eastern Sahara Atlas (Soua et al., 2009) and the Tunisian Atlas (Zouaghi et al., 2005; Jaillard et al., 2017). Nevertheless, Fig. 8 shows map extracts of commented satellite images of the Western Sahara Atlas where evident halokinetic-related structures can be recognized. They demonstrate the 
importance of salt mobilization, although it is not possible to link them either to active tectonics or passive movement due to halokinesis.
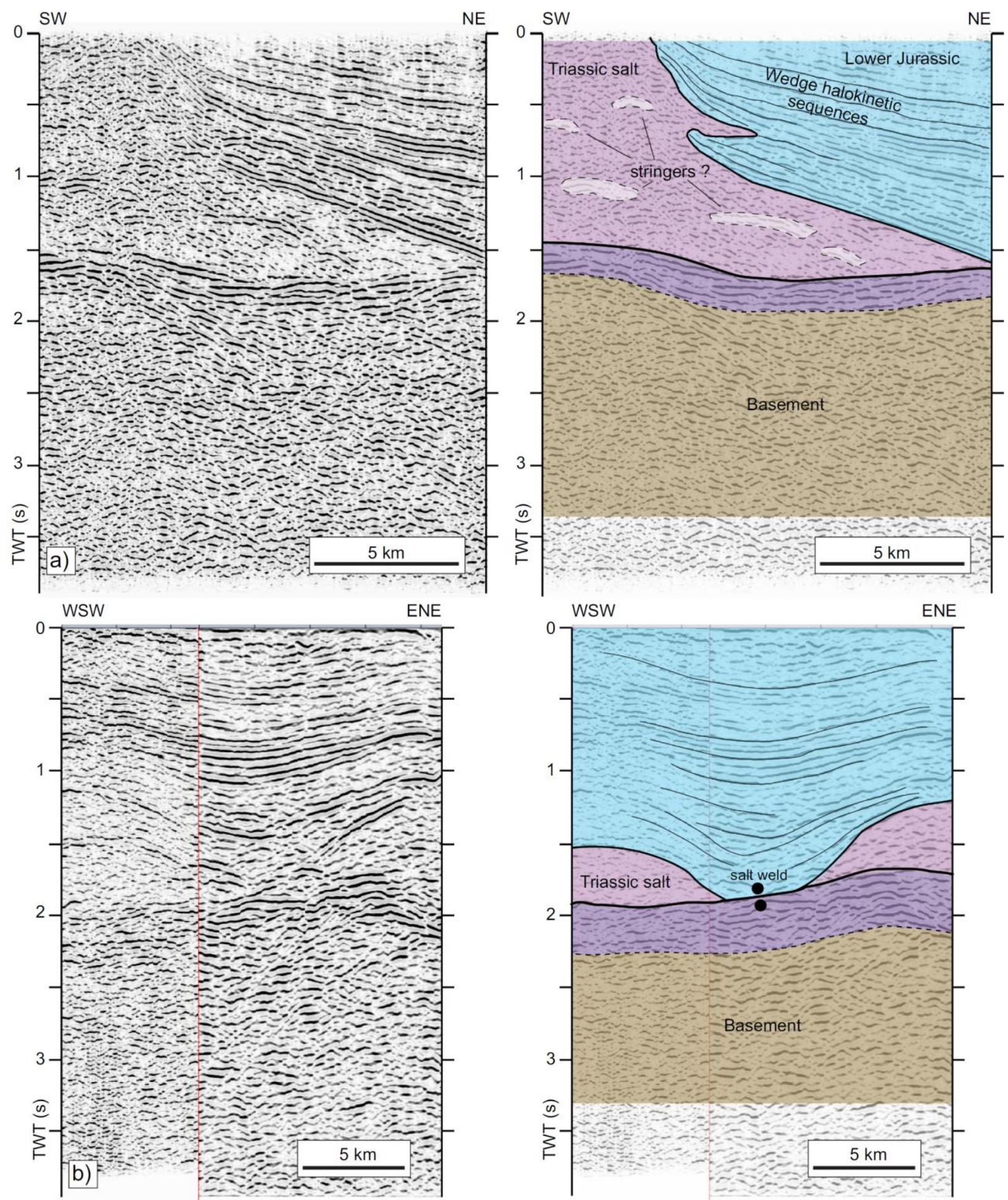

Fig. 7. Interpreted seismic reflection profiles a) and b) across several diapiric structures in the Western Sahara Atlas. See their location in Fig. 1b. Seismic profile in a) modified from Bracène et al. (2003) and in b) modified from Bracène (2002). 

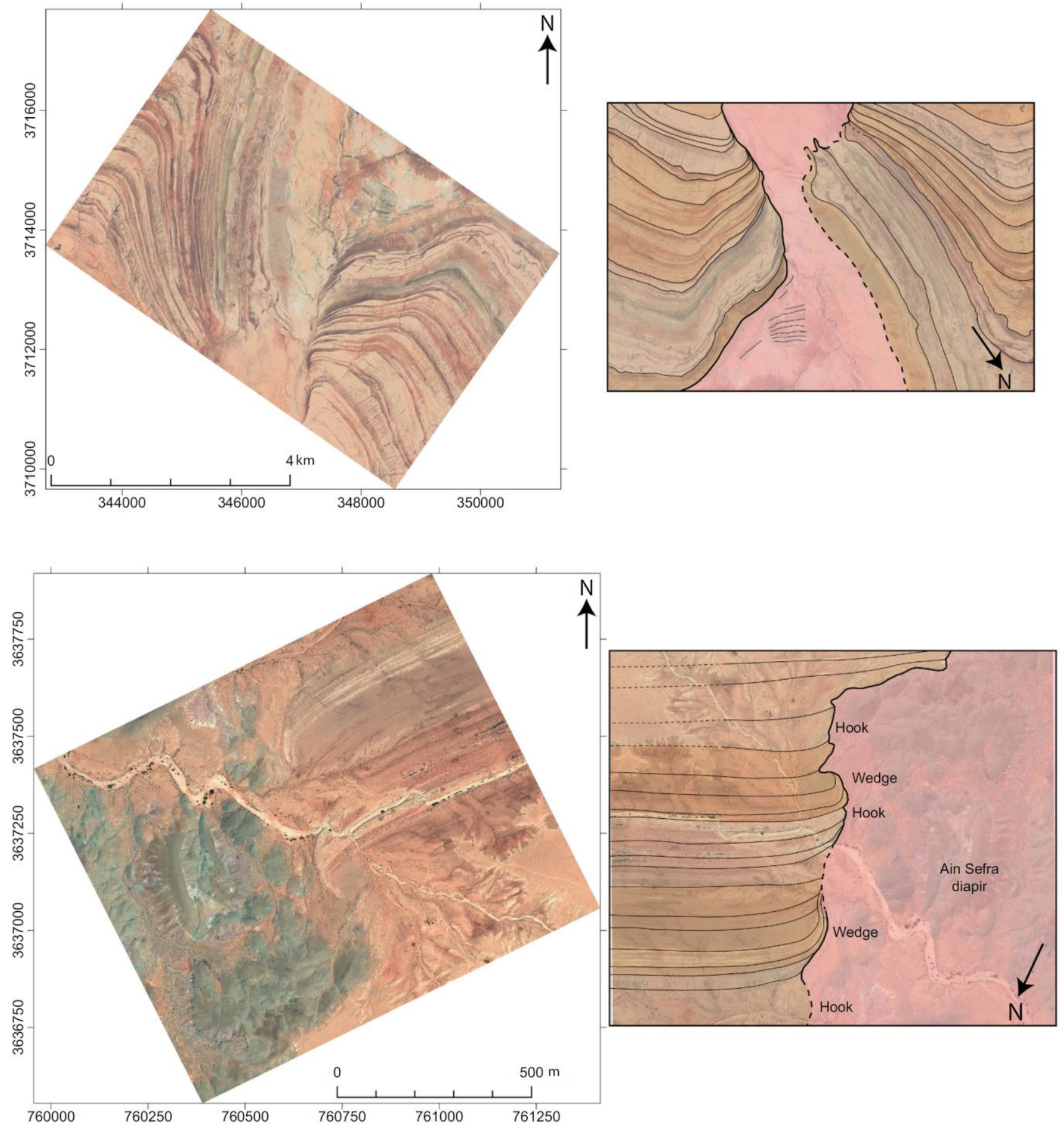

Fig. 8. Interpreted satellite images of diapir-related structures in the central and western Sahara Atlas. See their location in Fig. 1b. Satellite images from the Google Earth repository. Coordinates are in meters in Universal Transverse Mercator, zone 30 northern hemisphere and datum Nord Sahara 1959. 


\subsection{The Tendrara Basin}

The Tendrara Basin is located northwest of the Sahara Atlas, north of the Eastern High Atlas, and southwest of the Algerian High Plateaus (Figs. 1b and 4). Surface and subsurface data show that the Tendrara Basin corresponds to a NE-SW Mesozoic half-graben (Fig. 3), bounded to the south by a set of two main NE-trending basement extensional faults dipping to the NW (Fig. 9a and b). In general, the basin narrows and deepens to the SW, where it connects the Central High Atlas, and shallows to the NE (Fig. 10a), in the transition to the Algerian High Plateaus (Fig. 1b). In contrast to the other studied rim basins, the Tendrara Basin has not been completely incorporated into the Atlas fold-and-thrust belt, so it remains poorly inverted and widely displays the heritage of the extensional architecture.

\subsubsection{Paleozoic inheritance}

The Paleozoic structure below the Tendrara Basin can be inferred in the central and northeastern part of the basin, where a tabular and thin salt and suprasalt succession (less than 0,75 TWTs thick) allows for a better resolution in depth of the seismic reflection data (Fig. 10a). Even if only few subsurface data are available (Taki, 2012), the deep structure of the basin can be constrained thanks to a series of geological studies conducted in adjacent areas of the Algerian High Plateaus and Eastern High Atlas (e.g. Hoepffner et al., 2005; Hoepffner et al., 2006).

The Paleozoic stratigraphy for the Tendrara Basin can be partially obtained from several wells distributed between the central and northeastern part of the basin (Fig. 9c). The JK-1, located in the NE part of the basin, drilled a $>2300 \mathrm{~m}$ thick sequence of lavas, tuff and ashes with intercalations of marine sandstones, siltstones and mudstones Devonian-early Carboniferous in age (Taki, 2012 and references therein), based upon palynological data acquired on the interfingered marine sediments. The TE-1, TE-2 and TE-3 wells, in the central part of the basin (Fig. 9c), encountered $108 \mathrm{~m}, 103 \mathrm{~m}$, and $1403 \mathrm{~m}$ respectively of Carboniferous black silts, shales and carbonates (Taki, 2012). Therefore, two Paleozoic units are distinguished: a Devonian-early Carboniferous volcano-sedimentary unit overlain by a younger Carboniferous siliciclastic unit.

The seismic reflection data also show two main discontinuities in the Paleozoic units (Fig. 10a): an upper horizontal level located at the base of the lower salt unit (see continuous red line at $0,5-0,75$ TWTs depth); and a lower SE-dipping level located in an unknown position inside the Paleozoic succession (see dashed red line at 2 TWTs depth). Below the upper detachment, seismic reflection data depicts a series of horizontal reflectors that are onlapping an underlying SE-dipping seismic panel. To the $\mathrm{SE}$, the lower panel is folded and display a growth strata geometry. 

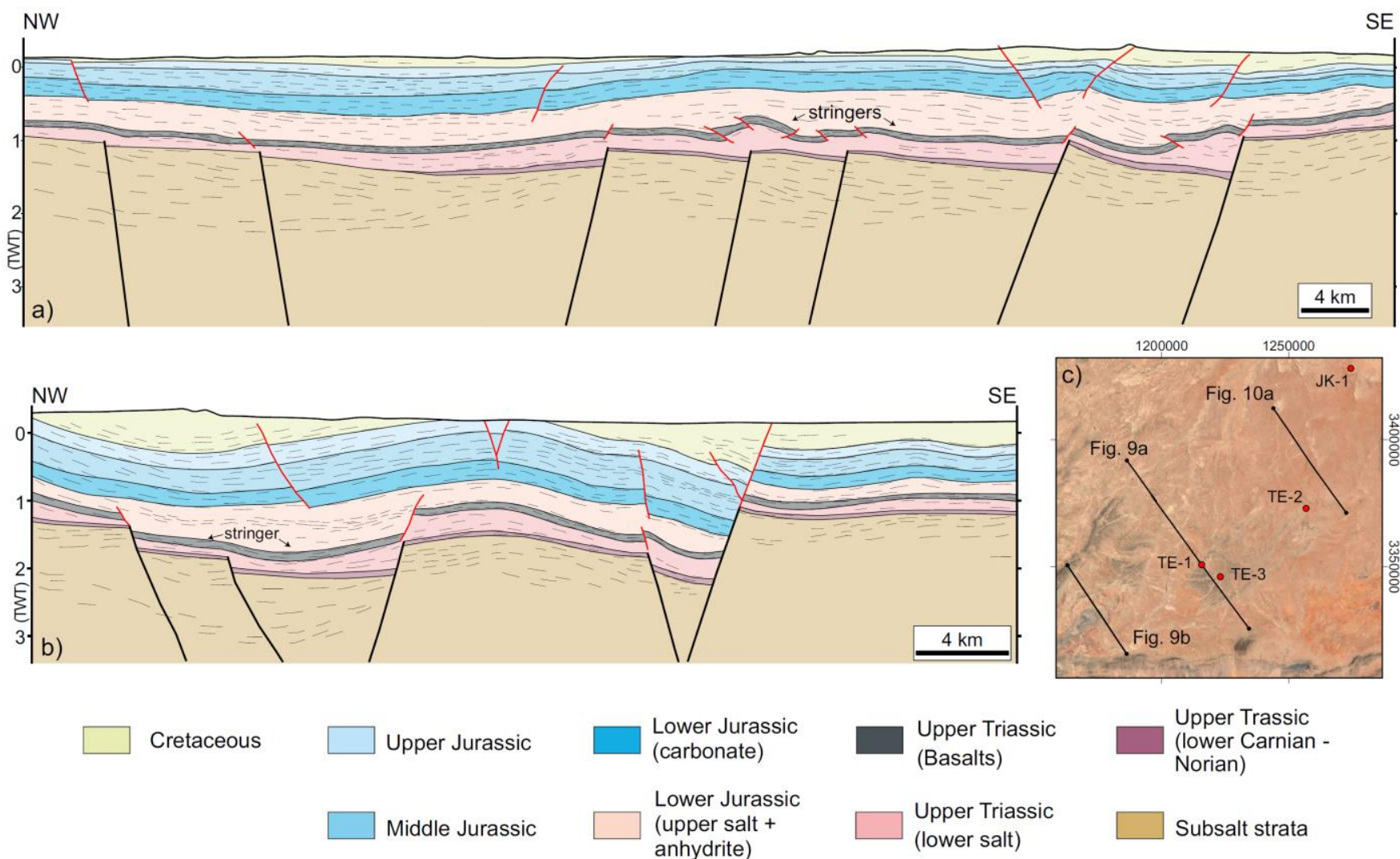

Fig. 9. Interpreted seismic reflection profiles a) and b), depicting the main structural features of the Tendrara Basin. Modified after Taki (2012). See their location in Figs. 1b. Satellite image in c) from the Google Earth repository. Coordinates are in meters in Universal Transverse Mercator, zone 30 northern hemisphere and datum WGS 1984.

Considering these sedimentary and structural features, the SE-dipping panel with growth strata geometries might be interpreted as deposited in half-grabens formed during the Devonian to early Carboniferous extension and controlled by NW-dipping normal faults (Fig. 10b). This is in agreement with geological observations over the Algerian High Plateaus and at the scale of whole Maghreb, where the Middle/Late Devonian to early Carboniferous successions were deposited in an extensional regime during the formation of the NW passive margin of Gondwana (Wendt, 1985; Eschard et al., 2010; Frizon de Lamotte et al., 2013). The sub-horizontal and onlapping unit instead, may be interpreted as deposited synchronously to the uplift of the underlying half-grabens (i.e. syn-contractinal unit during the Variscan Orogeny?); or alternatively, deposited during a later extensional pulse. Considering the first hypothesis, the late Carboniferous Variscan Orogeny that affected the Algerian High Plateaus could promote the inversion of the pre-existing half-grabens and the deposition of the late Carboniferous siliciclastic successions progressively onlapping the uplifted basins (see how depocenters are laterally shifted during inversion; Fig. 10b). In this scenario, shortening reactivated the previous extensional faults as reverse faults but also used the intra-Paleozoic weak rocks (e.g. the Silurian shales, the volcanic ashes or the marine marls) as décollement levels. As a result, an asymmetric pop-up structure could be developed involving the mildly inverted Middle/Late Devonian 
to early Carboniferous basins progressively covered by the late Carboniferous syn-orogenic sediments (Fig. 10b).

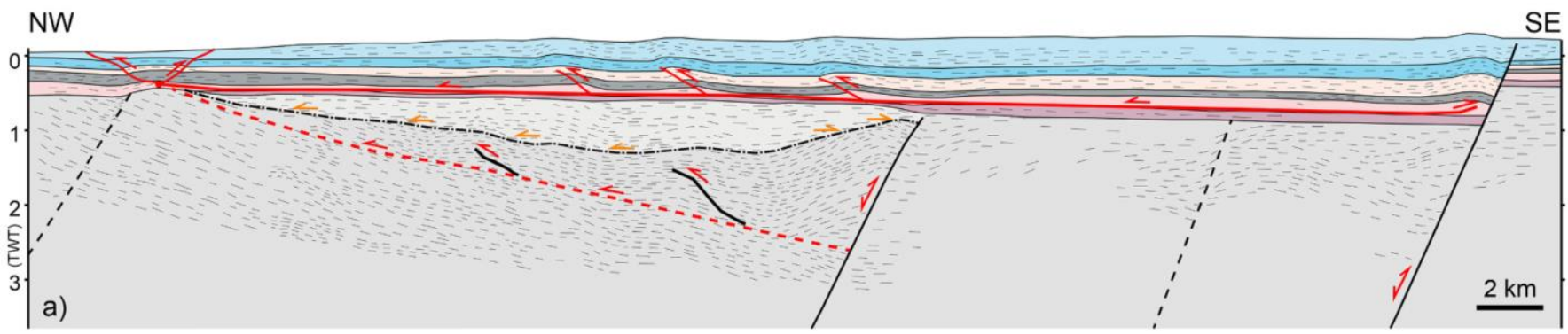

b) Qualitative restoration

1) Middle/Late Devonian? to early Carboniferous extension

\section{2) late Carboniferous inversion (Variscan Orogeny)}

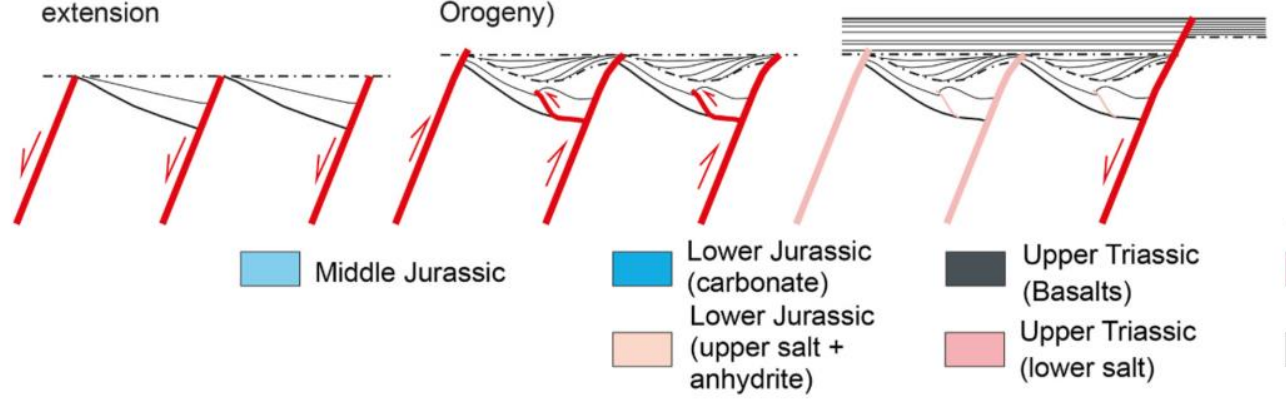

3) Triassic - Jurassic extension
4) late Cretaceous Cenozoic inversion

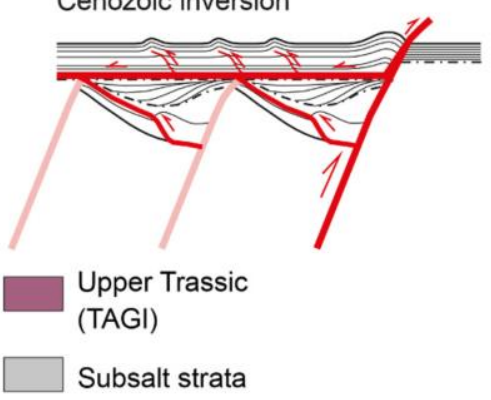

Fig. 10. Interpretation of a seismic reflection profile a) located in the northern part of the Tendrara Basin illustrating the geometry of the Paleozoic basement. Modified after Taki (2012). See its location in Figs. 9c. b) Qualitative sequential restoration depicting the Paleozoic, Mesozoic, and Cenozoic tectonic evolution of the basin. Note the implications of the Paleozoic structural inheritance for the subsequent Mesozoic extension.

\subsubsection{Mesozoic rifting}

The initial Paleozoic configuration constituted a structural inheritance for the subsequent deformations affecting the Tendrara Basin. The Triassic and Jurassic rifting events reactivated some of the preexisting Paleozoic extensional faults allowing the deposition of thick Triassic and Jurassic sequences showing growth strata (Fig. 9b).

The subsalt basement across the basin is deformed by minor thick-skinned conjugate extensional faults displaying two main orientations: NE-SW and NNE-SSW (Figs. 3 and 9). Because of this structural framework, the basin is compartmentalized in several sub-basins deepening in general towards the SW (compare Fig. 9a and b). The first syn-extensional deposits, the lower Carnian-Norian fine-grain to conglomeratic sandstones, are lying unconformable above the Paleozoic succession. The lower and upper salt units (upper Rhaetian and Hettangian-Sinemurian in age, respectively) show thickness 
variations over the faulted blocks: they are thicker in the hanging wall of the bounding thick-skinned faults and thinner in their footwalls. The total salt thickness increases towards the southeast and thinsout towards the NE part of the basin (Fig. 9a, b, and 10a). The maturity of the developed salt structures also varies along the basin. Tabular salt is present in the northern part of the basin (Fig. 10a), longwavelength salt-cored anticlines are common in the central part (Fig. 9a) and reactive diapirs represent the main building blocks of the basin towards the southwest (Fig. 9b). Additionally, in between both salt units, there is a continuous and stiff intra-salt layer constituted by the tholeiitic CAMP basalts acting as stringers. The deformation of this stiff layer seems to be constrained at some degree by the capacity of salt to move.

The suprasalt (i.e. Pliensbachian to Cretaceous rocks) thickness variations over the Tendrara Basin are controlled by salt migration coeval to extensional deformation characterized by thin-skinned faulting and drape folding (Fig. 9a and b). Above the upper salt unit, the Pliensbachian-Toarcian and Middle Jurassic carbonates are also thicker in the hanging walls of the bounding subsalt faults and thinner in the footwalls (Fig. 9a and b). Finally, the Upper Jurassic to Cenozoic succession does not depict major thickness variations and represents a post-rift stage in the tectonic evolution of the basin. However, in the southern part of the basin, seismic reflection data shows a minor depocenter that could have developed during the Upper Jurassic up to Cretaceous? (Fig. 9b).

\subsection{The Middle Atlas and the Guercif Basin}

The Middle Atlas represents a Cenozoic fold and thrust belt separating the so-called Western Meseta and the Algerian High Plateaus (Fig. 1b). With a NE-SW orientation, the Middle Atlas branches southward to the Central High Atlas and finishes northward sealed below the Neogene Guercif Basin. This mountain belt can be subdivided into two areas (Fig. 11): a formerly low-subsiding basin to the west, namely the "tabular" Middle Atlas; and the "folded" Middle Atlas to the east (Fig. 12), representing a more subsiding basin during the Mesozoic (Du Dresnay, 1988; Fedan, 1988; Charrière, 1990). This NE-trending branch of the Atlas system has its own rift timing that is somehow shared withits northern extension, presently buried below the Guercif Basin (Fig. 13). The deepest Neogene series in the Guercif Basin are as old as Tortonian up to the Pliocene-Quaternary (Colletta, 1977; Bernini et al., 1992; Zizi, 2002 and references therein). 


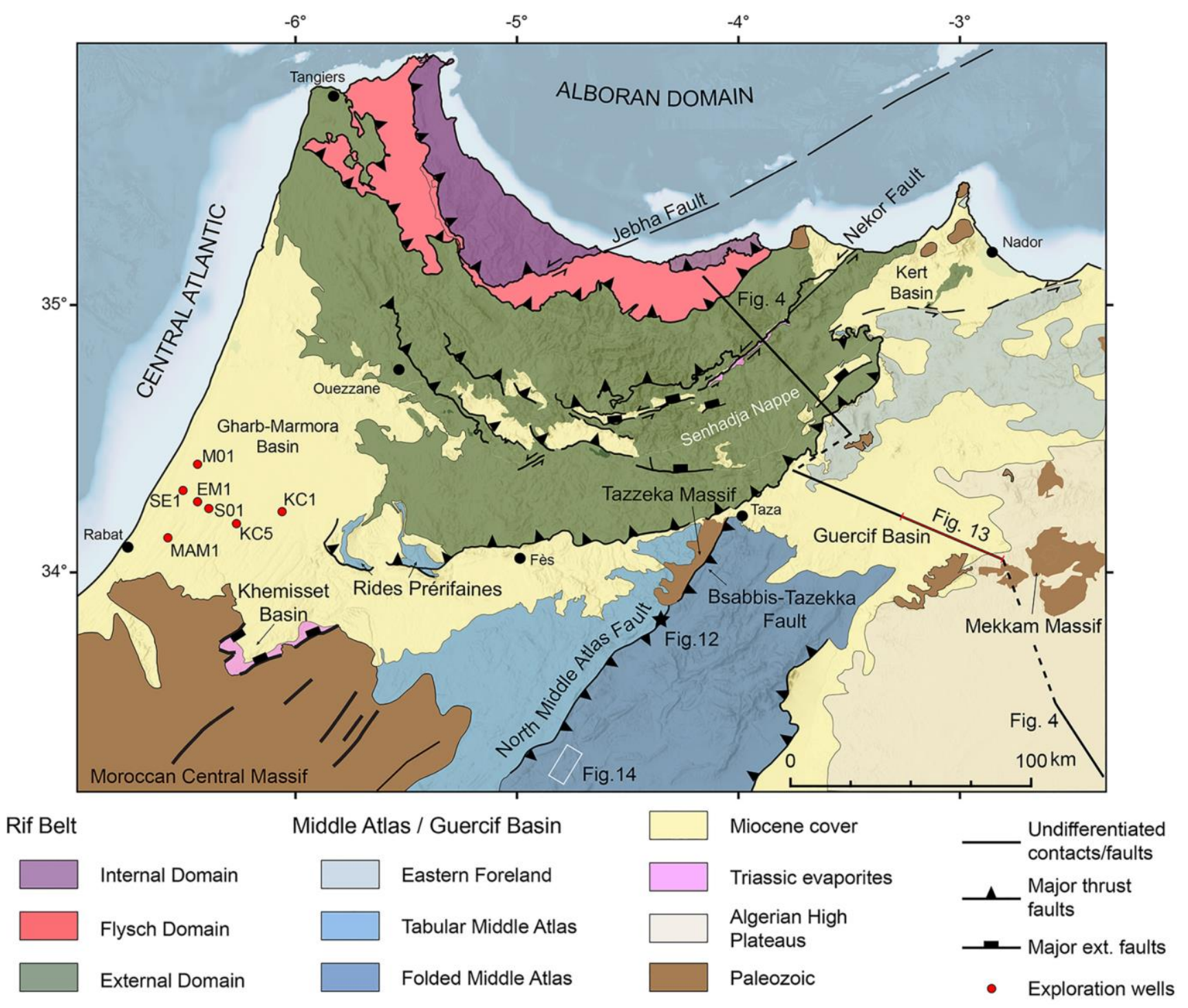

Fig. 11. Structural map of the Rif belt and the Middle Atlas / Guercif Basin. Modified from Gimeno-Vives et al. (2020b). Coordinates are in degrees in World Geodetic System 84.

\subsubsection{Paleozoic inheritance}

The main Paleozoic outcrop along the Middle Atlas and Guercif areas is the Tazekka massif, forming the NE limit of the tabular Middle Atlas (Fig. 1b and 11). This massif is characterized by folded and metamorphosed, mainly Ordovician in age, schists (Morin, 1973; Rauscher et al., 1982; Hoepffner, 1978, 1987; Charrière, 1990). Locally in the southwest, sediments can be as young as Devonian in age. In terms of deformation, the Tazekka massif shows deep Paleozoic levels with low-grade metamorphism (Hoepffner, 1978). The pre- and syn-orogenic Variscan deformation is guided inbetween important NE-SW major faults (e.g. the Bsabbis-Tazekka fault; Fig. 11) suggested to act as major transform faults, either accommodating transpression or transtension during the different deformation events (Hoepffner, 1978; Charrière, 1990). These faults were reactivated during the 
Mesozoic rifting, since (1) they control the significant thickness increase when crossing the boundary from the "tabular" to the "folded" Middle Atlas domains (Charrière, 1990; Fig. 12); and (2) the main depocenters of the "folded" Middle Atlas are separated from each other by NE-SW ridges (Fedan, 1988).
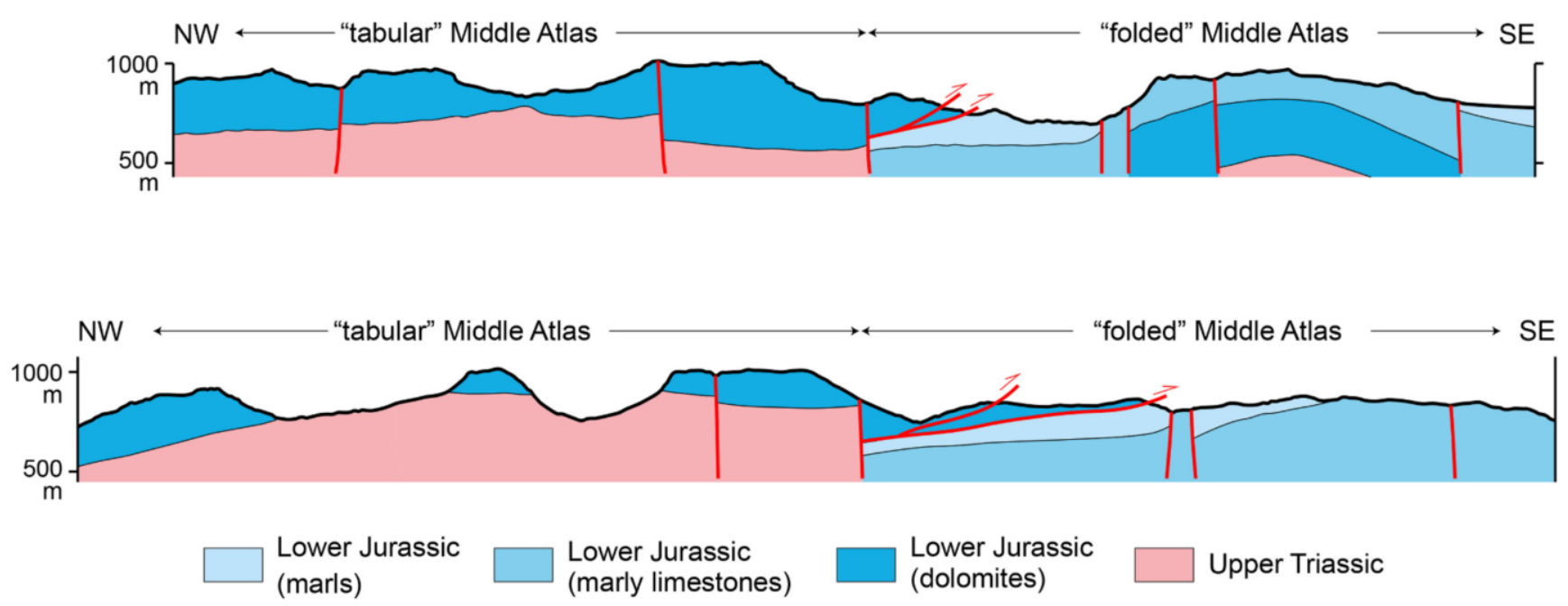

Fig. 12. Geological cross-sections depicting the limit between the folded and tabular Middle Atlas (modified from Charrière, 1990). See their location in Fig. 11.

\subsubsection{Mesozoic rifting}

The first event of Mesozoic rifting occurred during the Late Triassic and lasted up to the lowermost Early Jurassic (Salvan, 1984; Baudelot et al., 1990; Sabaoui, 1987; Lorenz, 1988; Oujidi et al., 2000; Lachkar et al., 2000; Courel et al., 2003). This extensional phase sets relatively small basins filled with siliciclastic sediments and evaporites -which were subsequently intruded by the basalts of the CAMP. From a structural point of view, a net geographical differentiation of the basin is often stressed in the literature (e.g. Choubert and Faure-Muret, 1960-1962; Oujidi et al., 2000): a clastic basin lies to the SW (i.e. the Kerrouchene Basin, Fig. 1b; Lorenz, 1976; Laville et al., 1995), whereas a salt-floored basin existed in the NE, below the present-day location of the Guercif Basin (Fig. 11), as evidenced by the mobilization of the Triassic salt at the cores of the anticlines deforming the whole stratigraphic pile (Bernini et al., 2000 and references therein). In between, there are relative structural highs without significant subsidence, recording thin clay-sandy sedimentation with some evaporitic levels interbedded with basalts (e.g. Charrière, 1990 for the "tabular" Middle Atlas). Extensional deformation resulted from the activity of NE-trending thick-skinned extensional faults, with N70-90॰ conjugate faults. For example, more than $1 \mathrm{~km}$ of throw has been considered for the major thick-skinned fault bounding the Kerrouchene Basin (Lorenz, 1976; Laville et al., 1995), whereas minor throws occurred on a large fault array inside the basin. The two structural orientations, active during Triassic times, are 
important regarding the subsequent evolution of the basin. They separated different blocks along the N70-90 direction that efficiently provided the persistence of a structural high between the Middle and Central High Atlas up to the Middle Jurassic (Choubert and Faure-Muret, 1960-1962; El Arabi et al., 2003).

After the first rifting event, a stable carbonate platform installed on top of the previous lowermost Early Jurassic sediments (Choubert and Faure-Muret, 1960-62; du Dresnay, 1988; Fedan, 1988). A second rifting phase occurred during the Pliensbachian to the early Toarcian times in both "tabular" and "folded" Middle Atlas (Fedan, 1988; Charrière, 1990) but is also seen at the Mekkam/Guercif transition on seismic lines (Zizi, 2002; Fig.13). Thick-skinned extensional faults controlled the sedimentation above tilted fault blocks with a general NE-deepening trend in the "folded" Middle Atlas (e.g. the Ain Nokra-Skoura-Zloul succession of tilted blocks, lying on the eastern side of the North Middle Atlas Fault (NMAF in Fig. 1b). However, west of the NMAF, the Guigou-Anocer block was poorly subsiding during the same period acting as a relative structural high (Charrière, 1990; El Arabi et al., 1999 and 2001). Overall, the field evidences in the "tabular" and western "folded" Middle Atlas, suggest that the progressive deepening of the sedimentary depocenters was accomplished through SE- and SW-dipping directions of the main thick-skinned faults (Charrière, 1990). Strikingly, the interpretation of the seismic lines and the well correlations in the Guercif Basin, showing the Middle Atlas continuation below the Neogene series (Zizi, 1996; Sani et al., 2000), denotes that extensional faulting mainly occurred within the same Toarcian/Aelian to Bajocian/Bathonian(?) time interval (Fig. 2). It thus advocates for an along-strike consistent record of these Early to Middle Jurassic extensional events.

Accordingly, the fault network controlling the sedimentation is divided into two main directions: (1) NE-SW oriented faults acting as the main separators between the principal depocenters, but also responsible in a minor way for the progressive staircase deepening towards the depocenters; and (2) transverse E-W to NW-SE faults that also promoted the development of a "staircase" of tilted fault blocks towards the main depocenters. More information about the deformations responsible for the onset of Middle Atlas rift on its eastern boundary are available from seismic lines within the Guercif Basin (Zizi, 1996; Sani et al., 2000). Here, a minimum of 2 TWTs of throw is recorded between the Mekkam high to the east and the subsiding Middle Atlas to the west along a single major WNW-dipping fault (Fig. 13). Considering that the Cenozoic inversion minimized the amount of extensional motion along the fault plane, the transition towards the basin really was abrupt along this steep and WNWdipping major fault. Salt-related structures are not evidenced during this phase of rifting. Only seismic imaging suggests that minor halokinesis might have played a secondary role in early structuring of 
some areas in the Guercif Basin (e.g. Sani et al., 2000; their Fig. 3 and some unexplained thicknesses reductions without obvious faulting).

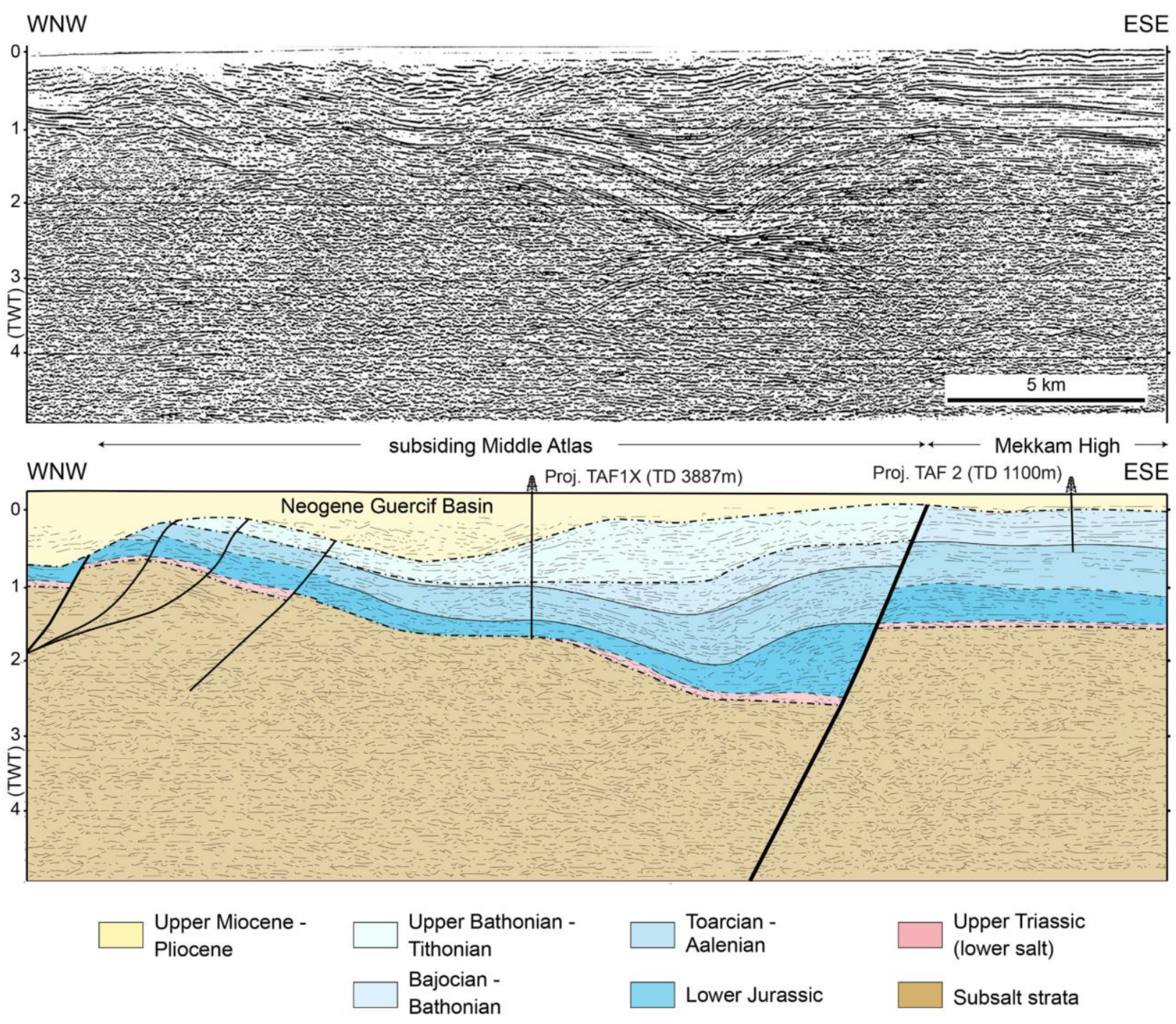

Fig. 13. Interpretation of the seismic reflection profile across the Middle Atlas and the Mekkam High (modified from Zizi, 1996). See location of the seismic reflection profile in Fig. 11.

An important deepening phase was widely recorded in the Middle Atlas during the sedimentation of lower to mid-Bajocian marls, which in some parts of the basin were deposited unconformably over older deposits (du Dresnay, 1988; Charrière, 1990). This second deepening cycle ended with the progressive filling of the basin, the transition from shallow marine to shoreface environments and the final development of red beds from Middle-Late Bathonian to Hauterivian times. These are in turn capped by a widespread unconformity that is Barremian/Aptian(?) in age (Charrière and Haddoumi, 2016). During the Bajocian to Bathonian-Callovian times, a series of elongated ridges were developed separating different depocenters (Fedan, 1988; Charrière, 1990; Charrière and Haddoumi, 2016). 
These ridges represented relative structural highs against which the growth strata developed (e.g. see the northeastern Oudiksou syncline border against the Lakhchabt salt wall in Fig. 14; Laville, 1977; Fedan, 1977; Charrière, 1990). Adjacent to these ridges there are growth strata depicting angular unconformities (see cross-sections A, B, C, and D in Fig. 14), with olistolites and occurrences of bipyramid quartz (coming from the Triassic salt) in contemporaneous sediments. These field evidences point out to a strong coupling between the active growth of salt ridges and the rapid subsidence attesting for active halokinesis at the time. The possibility of some additional rifting phases has been suggested by Zizi (2002) based on the interpretation of the seismic reflection profiles in the Guercif Basin. This author suggests that extension had acted from the end of Early Jurassic to Late Jurassic. In fact, as far as it concerns the Middle Atlas, no major extensional phase could be recognized after the Toarcian or only as minor events (between Aalenian and Bajocian; Frizon de Lamotte et al., 2008).

Strikingly, the interpretation of the seismic lines in the Guercif Basin, showing the Middle Atlas continuation below the Neogene series (Zizi, 1996; Sani et al., 2000), denotes that extensional faulting mainly occurred in Callovian to Upper Jurassic times (Fig. 13). Moreover, well correlations in the Guercif Basin also attest for syn-depositional lateral thickness variations Bajocian(?)-Bathonian in whose origin is not clear, but suggested by Sani et al., (2000) to still represent extensional activity (see their Fig. 4). Finally, extension post-dating Hauterivian times is not recorded in the Middle Atlas and the first stages of inversion followed the main High Atlas tectonic schedule (Frizon de Lamotte et al., 2008).

\subsection{The Rif Basin}

The Rif belt is in northern Morocco at the junction between the Mediterranean Sea and the Central Atlantic Ocean (Fig. 1b). It results from the Cenozoic interaction between the African and Iberian plates with the Alboran Domain in between (Durand-Delga et al., 1960-1962; Suter, 1965; Chalouan et al., 2008; Gimeno-Vives et al., 2020b). The Rif belt is subdivided into three main structural domains (Fig. 11): the internal Rif (Alboran domain), the Flysch and the External Rif. In the frame of this study, we focus exclusively on the external Rif, where remnants of the NW Africa paleomargin are preserved (Favre et al., 1991; Favre, 1992). From SE to NW, the external Rif is subdivided into three structuralpaleogeographic domains: the Prerif, the Mesorif and the Intrarif (Suter, 1965; Favre, 1992), defining the proximal, the necking zone and distal paleomargin, respectively (Gimeno-Vives et al., 2019 and Gimeno-Vives et al., 2020a; Michard et al., 2020).

\subsubsection{Paleozoic inheritance}

Very little information about the structure and Paleozoic tectonic evolution exists in the geological literature dealing with the external Rif. The main reason is that the Upper Triassic evaporites acted as 

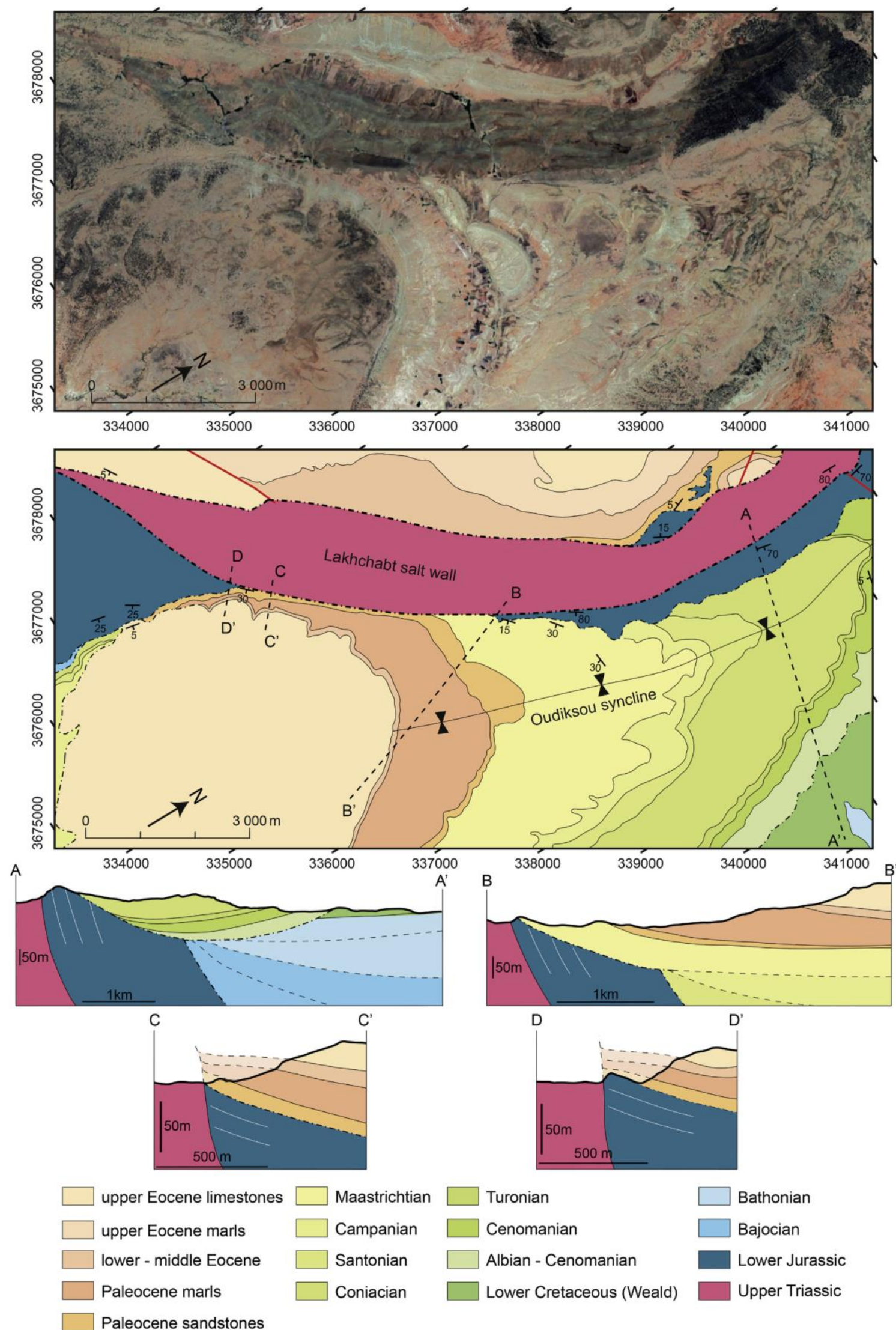

Fig. 14. Satellite image and associated geological map of the Oudiksou syncline adjacent to the Lakhchabt salt wall ("folded" Middle Atlas). Geological map modified from Charrière (1990), and cross-sections reinterpreted from his work. Satellite image from the Google Earth repository. Coordinates are in meters in Universal Transverse Mercator, zone 30 northern hemisphere and datum Nord Sahara 1959. See the location of the geological map in Fig. 11. 
a décollement level during both the Mesozoic and Cenozoic tectonic events making, in general, the underlying Paleozoic levels unreachable (Gimeno-Vives et al., 2019 and 2020b). However, basement blocks constituted of gneiss, micaschist, kinzigite, and Paleozoic sedimentary rocks have been recognized embedded in Triassic evaporites (Frizon De Lamotte, 1985; Lacoste, 1934).

In the Gharb-Marmora basin (i.e. representing the foreland of the Rif belt; Fig. 11), a series of wells (MAM1, SE1, M01, EM1, S01, KC5 and KC1) intersect thick upper Miocene strata and thin Mesozoic strata before reaching the Paleozoic succession (Suter, 1980). To the east, in the Tazekka Massif, upper Miocene strata are lying directly over the Paleozoic succession without Mesozoic rocks in between. Therefore, the horst-and-graben geometry observed in the foreland continues below the chain and the major NE-trending faults (i.e. the Nekor Fault Zone) are likely inherited from the Variscan fault array. From the map depicted in Fig. 11 it can be inferred that, beneath the Rif belt, the remnants of the Variscan belt continue but most likely reworked by the stretching developed in the distal part of the margin during the subsequent Triassic and Jurassic extensional phases.

\subsubsection{Mesozoic rifting}

The NW Africa paleomargin encompassed a complex and polyphased rifting history during the Mesozoic. The first rifting event, occurring during the Late Triassic, remains puzzling since there are very few outcrops presenting pre-Keuper strata. Nevertheless, this rifting event is well defined in adjacent Mesozoic basins that have remained almost unaffected by the subsequent Alpine inversion (e.g. the Khemisset Basin and the Rides Prérifaines see Fig. 11; Et-Touhami, 2000; Zizi, 2002; Sani et al., 2007). Although the Triassic architecture cannot be properly recognized, the existence of a Late Triassic basin is evidenced by the presence of extensive Triassic evaporites cropping out over the external Rif. The importance of this first rifting phase remains difficult to evaluate. However, a coeval thinning of the lithosphere is certain, since large mafic magmatic additions were emplaced within the continental crust at about $200 \mathrm{Ma}$ (Gimeno-Vives et al., 2019; Haissen et al., 2021). Such magmatism is expressed in the Rif under the name of Mesorif Gabbroic Complex "MGC" and has been attributed to the Central Atlantic Magmatic Province (CAMP).

After the emplacement of this widespread magmatism and during the lowermost Jurassic, a large carbonate platform deposited coinciding with a period of relative tectonic quiescence (Papillon, 1989; Favre, 1992). Subsequently, a second rifting phase occurred, characterized by a sudden deepening of the basin, from the Toarcian to Upper Jurassic times. Contrary to the first Late Triassic extension, this phase resulted on successful rifting, thus completing the oceanization and the NW-SE opening of the Maghrebian Tethys. In the Mesorif, gabbroic rocks are overlaid by dismembered and discontinuous 
blocks of Lower Jurassic carbonates, and covered by Middle to Upper Jurassic sediments. Such a geometry indicates a decoupling between the suprasalt strata and the basement along the Triassic evaporites. Subsalt deformation allowed the exhumation of the Mesorif Gabbroic Complex up to the surface throughout large detachment fault (see a restored cross-section in Fig. 15).

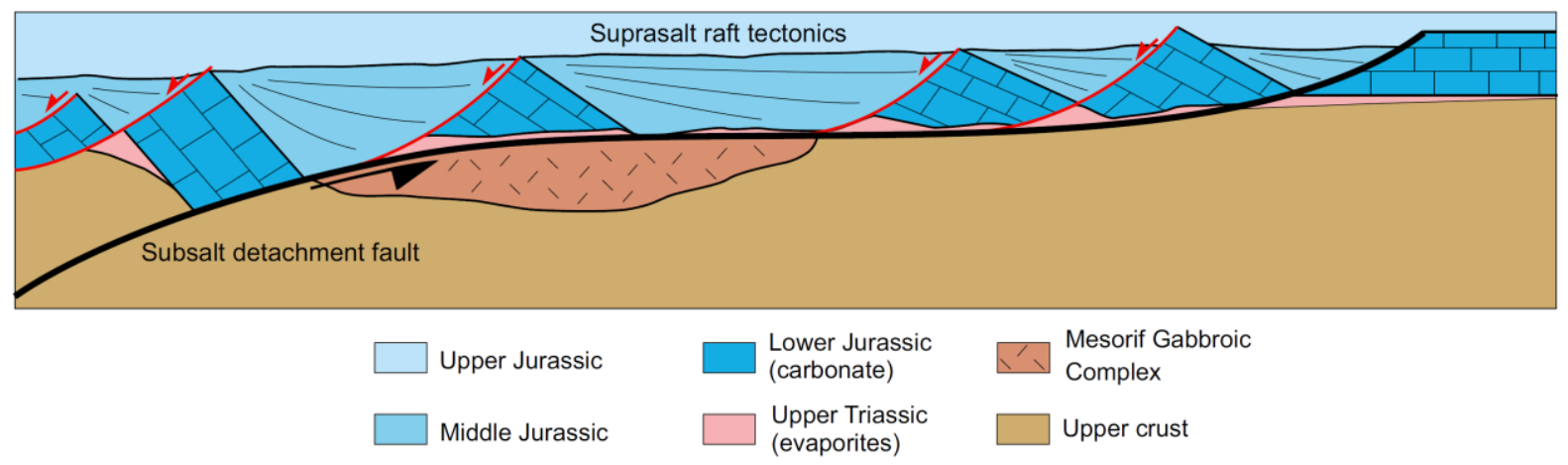

Fig. 15. Restored cross-section in the Rif Basin during Late Jurassic times, depicting the exhumation of the Mesorif Gabroic Complex along a low-angle extensional fault and associated raft-tectonics extensional system in its hangingwall. Modified from Gimeno-Vives et al. (2020a).

On the other hand, in the detachment hanging wall, this rifting phase is dominated by raft tectonics recording the stretching and dismembering of the Lower Jurassic platform over the Upper Triassic evaporites. Importantly, coeval salt movements are observed throughout the development of salt diapirs in the distal part of the margin (Gimeno- Vives et al., 2019). These features are well documented in the syn-rift sequence Toacian-Bajocian in age, presenting thickness variations and wedge geometries against diapiric structures. The most distal part of the margin, exposed in the Intrarif, exhibits serpentinized peridotites, interpreted as exhumed mantle (Michard et al., 1992; 2007; Gimeno- Vives et al., 2019). The Uppermost Jurassic limestones and calcschists resting directly on top (Fig. 15), suggests a Late Jurassic mantle exhumation age and subsequent drifting, which gave birth to the Maghrebian Tethys.

\section{Discussion}

Regional observations based on geological and seismic evidences, showed that the pre-orogenic and orogenic structures related to the Variscan belt controlled the extensional deformation during the formation of the NW Africa paleomargin (see Table 1 for a summary of the ages of the tectonic events in NW Africa) and, consequently, the localization and evolution of the Mesozoic rifts. Firstly, it is important to understand how this control works. Then, we will discuss the timing of the Mesozoic rifting events from one basin to the other, in relationship with the geodynamics of the Atlantic and Tethys oceans. And finally, we will consider the timing and modalities of the rift inversion. 
Comparison of the rifting timings in the different studied basins of NW Africa.

\begin{tabular}{|c|c|c|c|c|c|}
\hline & & Sahara Atlas & Tendrara Basin & Middle Atlas / Guercif Basin & Rif Basin \\
\hline \multirow[t]{2}{*}{ Paleozoic } & Extension & Unknown & $\begin{array}{l}\text { Inferred Cambrian to early } \\
\text { Carboniferous }\end{array}$ & $\begin{array}{l}\text { Inferred Ordovician to } \\
\text { Devonian }\end{array}$ & Unknown \\
\hline & Inversion & $\begin{array}{l}\text { upper Carboniferous (dated } \\
\text { by igneous intrusions of } 298 \\
\text { Ma) }\end{array}$ & Inferred upper Carboniferous & $\begin{array}{l}\text { Inferred upper } \\
\text { Carboniferous }\end{array}$ & Inferred upper Carboniferous \\
\hline \multirow[t]{3}{*}{ Mesozoic } & Permo-Triassic rifting & $\begin{array}{l}\text { Late Triassic (NE- to ENE- } \\
\text { trending faults sealed by the } \\
\text { CAMP basalts) }\end{array}$ & $\begin{array}{l}\text { Carnian - Norian and Rhaetian } \\
\text { (NE- to NNE-trending faults sealed } \\
\text { by the CAMP basalts) }\end{array}$ & $\begin{array}{l}\text { Late Triassic (emplacement } \\
\text { of the CAMP magmatic } \\
\text { intrusions) }\end{array}$ & $\begin{array}{l}\text { Inferred Late Triassic } \\
\text { (emplacement of the Mesorif } \\
\text { Gabbroic Complex, CAMP } \\
\text { equivalent) }\end{array}$ \\
\hline & $\begin{array}{l}\text { Jurassic rifting } 1 \\
\text { (Atlantic domain) }\end{array}$ & $\begin{array}{l}\text { Toarcian (reactivation of the } \\
\text { NE-trending extensional } \\
\text { faults }\end{array}$ & $\begin{array}{l}\text { Pliensbachian - Toarcian } \\
\text { (reactivation of the NE- to NNE- } \\
\text { trending faults) }\end{array}$ & uppermost Pliensbachian & \\
\hline & $\begin{array}{l}\text { Jurassic rifting } 2 \\
\text { (Maghrebian Tethys } \\
\text { domain) }\end{array}$ & early Bathonian & Middle Jurassic & $\begin{array}{l}\text { middle Bajocian to } \\
\text { Callovian }\end{array}$ & $\begin{array}{l}\text { Toarcian to Upper Jurassic } \\
\text { (successful rifting and } \\
\text { oceanization) }\end{array}$ \\
\hline
\end{tabular}

\subsection{A prominent Paleozoic inheritance}

The Atlas Mesozoic rift system developed over a segment of the Variscan belt (i.e. Moroccan Variscides). Given the absence of continental suture in the Moroccan Variscides, this orogeny is considered as an intraplate orogeny entirely deriving from the NW passive margin of Gondwana (Simancas et al., 2009; Michard et al., 2010). Before the Variscan orogeny, this domain was the site of two major periods of rifting, during the Cambrian-Ordovician and Middle/Late Devonian to early Carboniferous times, respectively (Hollard et al., 1982; Wendt, 1985; El Hassani, 1994; Soulaimani et al., 2004; Wendt et al., 2006; Simancas et al., 2009; Eschard et al., 2010; Frizon de Lamotte et al., 2013; Fig. 2). The later was followed by the Variscan tectonic inversion during the late Carboniferous-early Permian (Chopin et al., 2014; Wernert et al., 2016; Delchini et al., 2018). The NE- to ENE-trending Late Devonian-Early Carboniferous rift basins (Fig. 16a) are of crucial importance for the subsequent tectonic evolution of the Moroccan Variscan belt which directly results from the inversion of these basins (Fig. 16b). A set of arguments shows that the rift basins were particularly deep and hot with high paleogeothermal gradients (Chopin et al., 2014; Wernert et al., 2016; Delchini et al., 2018; Lahfid et al., 2019), similarly to what has been observed in the Aptian-Albian Cretaceous Pyrenean basins (Vacherat et al., 2014; Clerc et al., 2015).

In NW Africa, the general structural array for the Variscan deformation resulted from the inversion of the previously hot Lower Carboniferous basins; for this reason, the extension and the distribution of these basins represents a key factor. During their inversion, the former basin horsts emerged as "popup" structures, meanwhile the exhumed deeper parts of the basins reveal a scarce Barrovian metamorphism (e.g. in the Rehamna massif: see Choping et al., 2014; Fig. 1b). There is not complete agreement on the condition for tectonic inversion in the intraplate setting of the NW Africa Variscides. However, it is largely accepted that the pre-orogenic conditions that allowed accumulating heat likely promoted the tectonic inversion (e.g. for the Rehamna area: Chopin et al., 2014; Wernert et al., 2016; 
or for the Jebilet Massif: Delchini, 2018; Delchini et al., 2018; Fig. 1b). The compression produced a general NE-SW to E-W structural trends, accounting for the overall present-day structure in Paleozoic outcrops, showing alternation of Lower Paleozoic topographic highs with Lower Carboniferous basins. The inversion of former extensional basins occurred in two main phases with distinct orientations: a first compression that was oriented NNW-SSE, followed by a second one oriented WNW-ESE (Chopin et al., 2014; Delchini et al., 2018; Fig. 16b).

The trends of Mesozoic rift basins follow almost strictly the structural grain of the Variscan Belt. In particular, it is striking to note how it follows the NE-SW Paleozoic inheritance in the Middle Atlas, Rif and Tendrara basins, whereas it becomes E-W in the Tamlelt area, as the former Paleozoic faults bend (e.g. Houari and Hoepffner, 2003) before trending NE-SW again in the Sahara Atlas (compare Fig. 16b and c). However, the Mesozoic basins indifferently developed over both former basin horsts ("pop-up" structures, e.g. Middle Atlas, on top of Tazekka Paleozoic high) or former Lower Carboniferous basin (e.g. Tendrara Basin). This configuration may suggest that after the Permian emplacement of magmatic intrusions (El Hadi et al., 2006) and at the onset of the Mesozoic rifting period, the lithosphere was thermally re-equilibrated with a flat topography forming a wide levelling surface. So, at the beginning of the Triassic and beneath the whole area, the lithospheric mantle could be homogeneously replaced by more fertile lithospheric mantle (e.g. the consequence of the "mantle plume" effect and related asthenospheric upwelling). So, globally there is a transition from numerous uppermost Carboniferousearly Permian riftings likely triggered by thermal insulaton of the Pangea continental aggregation and subsequent large-scale melting and global weakness of the lithosphere, to a scenario of Mesozoic rifting systems that are progressively more confined along inherited structural trens and influenced by a relative increase of the "mantle plume" effect (Frizon de Lamotte et al., 2015). So, this might suppose a "reset" of the Paleozoic thermal insheritance, thus the subsequent Mesozoic rifting events will be progressively more constrained along the main inherited structural (Variscan) trends.

\subsection{A generalized rifting episode during the Late Triassic}

Overlying a mature (i.e. flattish) topography, the oldest Mesozoic syn-rift sediments are fine grain to conglomeratic sandstones dated lower Carnian-Norian in the Tendrara Basin (Taki, 2012 and references therein). Overlying this initial siliciclastic sequence, syn-rift Rhaetian evaporites (Keuper Fm.) deposited in fault-bounded basins (Fig. 3). The Late Triassic sedimentary sequences were then overlain by the continental flood basalts dated around $200 \mathrm{Ma}$ (Marzoli et al., 1999; Knight et al., 2004; Verati et al., 2007), pertaining to the CAMP (see its distribution in Fig. 16c). In the study area, the CAMP basalts clearly post-date the Triassic rifting. However, the restricted sedimentary environments and evaporitic sedimentation lasted up to the Sinemurian, so being partly post-rift by reference to the 

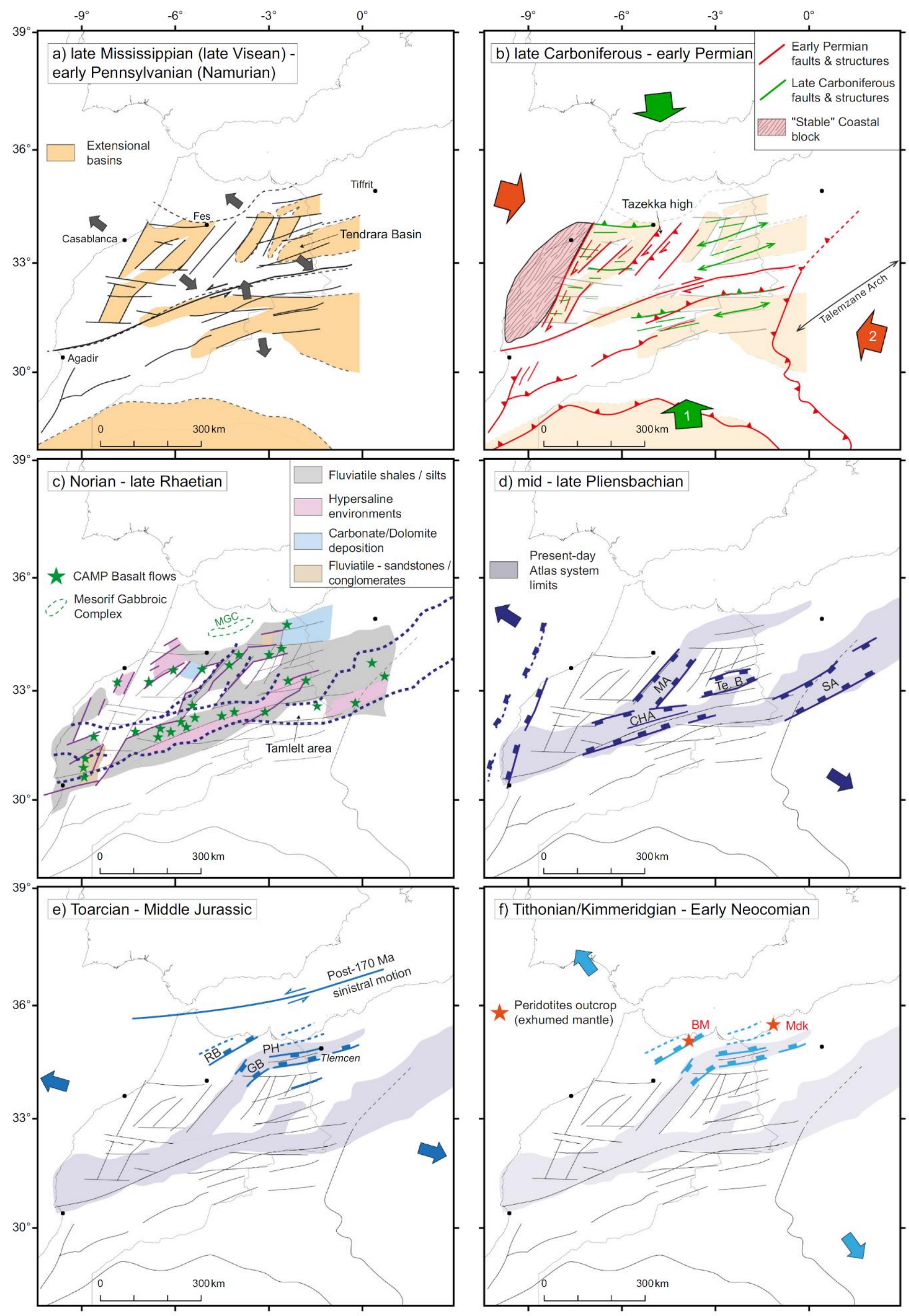

f) Tithonian/Kimmeridgian - Early Neocomian

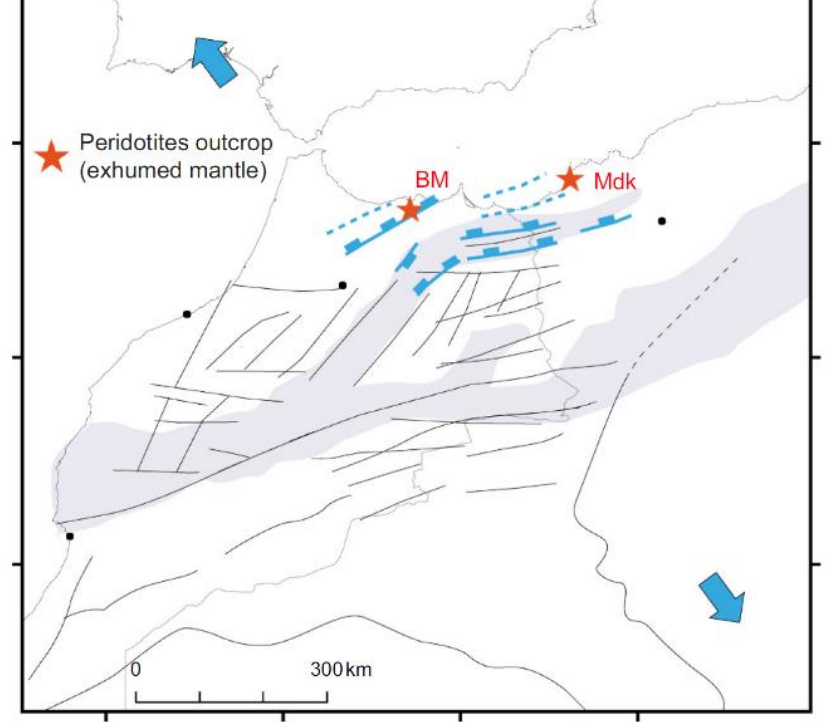


Fig. 16. Time-sequenced tectonic maps of NW Africa depicting: a) the location of the main subsiding areas and the rifting trend during Late Visean to Namurian times (after Hollard (1967), Wendt and Aigner (1985), Piqué and Michard (1989), Bouabdelli (1989), El Hassani (1994), Zahraoui (1994), Fabre (2005), Hoepffner et al. (2005), Wendt et al. (2006); b) the main trends of the Variscan Belt re-using the previous Paleozoic extensional features; c) Upper Triassic basins indifferently developed over both former lower Paleozoic horsts and Lower Carboniferous rift basins (Oujidi et al., 2000; Courel et al., 2003; Meddah et al., 2017; Gimeno-Vives et al., 2019; El Hachimi et al., 2020); d) mid to late Pliensbachian basins associated with the rifting along the Central Atlantic margin (CHA: Central High Atlas; MA: Middle Atlas; Te. B.: Tendrara Basin; SA: Sahara Atlas; e) the north-eastward jump of rifting/spreading of the Central Atlantic domain accommodated by a major EW transform fault system and activating NE- to ENE-trending extensional faults in the Maghrebian Tethys domain during Toarcian - Middle Jurassic times (RB: Rif basin; GB: Guercif Basin; PH: "Pays des Horst"); f) hyper-extension in the Maghrebian margin triggering mantle exhumation and the start of oceanic accretion in the Maghrebian Tethys ("BM" and "Mdk": Beni Malek and Medakh peridotite bodies, respectively). All map coordinates are in degrees in World Geodetic System 84.

Triassic rifting. The presence of restricted basins allowing the sedimentation of thick Lower Jurassic evaporite successions could be the consequence of the formation of volcanic ridges combined with the thermal subsidence related to previous rifting in the northern central Atlantic continental margin.

In the Rif, the end of the Upper Triassic rifting episode is marked by the emplacement of the Mesorif Gabbroic Complex within the continental crust (Gimeno-Vives et al., 2019 and Gimeno-Vives et al., 2020a; Haissen et al., 2021; Fig. 16c). For these authors, the Mesozoic Gabbroic Complex pertain to the CAMP underlining the importance of this magmatic event at the scale of the NW African paleomargin. The occurrence of intraplate magmatism might be related to the existence of inherited tectonic/thermal features weakening the continental crust. The origin of the Upper Triassic magmatism and the related emplacement of the Mesorif Grabbroic Complex in the Rif might be favored by the presence of major faults inherited from the Variscan Orogeny or even older tectonic events. These crustal-scale faults separating different accreted Precambrian to Paleozoic terranes (Michard et al., 2010, their Fig. 12) could be reactivated, as the weaker parts of the lithosphere, thus promoting the localization of extensional faulting during the subsequent Mesozoic rift. So, in a similar way than the Paleoproterozoic shear zones onshore Angola reactivated during the opening of the South Atlantic Ocean and localizing syn-rift and syn-exhumation Cretaceous magmatism (e.g. Lucapa and/or Sumbe shear zones: Alberti et al., 1999; Eley et al., 2008; Jelsma et al., 2018), the major fault zones in NW Africa could connect the subcontinental mantle and the crust acting as preferent conduits for the emplacement of magmatic additions into the weakened lithosphere during the Mesozoic rifting.

\subsection{Differentiated Jurassic rifting events and opening of the Maghrebian Tethys}


After the emplacement of the CAMP basalts everywhere and the Mesozoic Gabbroic Complex in the Rif Basin (Gimeno-Vives et al., 2019), rifting resumed along the Central Atlantic and in the Atlas systems (Figs. 16d). Along the Central Atlantic, the precise timing of this new rifting episode has been debated (Sahabi, 2004; Labails et al., 2010; Biari et al., 2017). However, it is clear that the first oceanic crust occurred no later than $175 \mathrm{Ma}$ in the Atlantic Ocean domain (Klitgord and Schouten, 1986) and that a slow-extension corresponding possibly to hyper-extension of the continental crust and coeval mantle exhumation developed between 195 (late Hettangian) and 175 Ma (late Toarcian) (see discussion in Biari et al., 2017). As suggested by Frizon de Lamotte et al. (2011), in the northern part of Central Atlantic domain, rifting/spreading propagated north-eastward at the Bajocian period, towards the incipient Maghrebian Tethys (Sibuet et al., 2012; Fernandez, 2019). At that time, the relative left-lateral movement between Africa and Newfoundland-Iberia was accommodated along a lithospheric-scale EW transform fault system (Fig. 16e), likely inherited from the Variscan orogeny (this cannot be argued through field evidences but comes up as a necessary constraint in the Late Variscan stages and the Pangaea assembly; e.g. Edel et al., 2018). This major structure controlled the localization of the incipient Maghrebian Tethys (Sallarès et al., 2011; Leprêtre et al., 2018a; Fernandez, 2019).

In the Atlas System (i.e. the Middle Atlas, the Central High Atlas, Tendrara Basin and the Sahara Atlas), the Jurassic rifting episode resumed by the middle to late Pliensbachian (189 Ma) and likely was over by the Toarcian (Fig. 16d). In the Central High Atlas, this is confirmed by coeval salt mobility as proposed by several authors (e.g. Saura et al., 2013; Joussiaume et al., 2014; Moragas et al., 2017), but a similar timing could be also argued for the Sahara Atlas (Vially et al., 1994; Elmi et al., 1998; YellesChaouche et al., 2001), the Middle Atlas (Fedan, 1988; Charrière, 1990) and our new results in the Tendrara Basin. By the Middle Jurassic, halokinesis stopped along the margins of the Central High Atlas Basin in agreement with the end of the rift-related extension at that time. Salt mobility continued passively in the center of the basin at least up to the Bathonian. In the Middle Atlas, the extension associated to this tectonic phase is known to have stopped during Middle Toarcian (Fedan, 1988; El Arabi et al., 2001), however it seems to have persisted in northernmost parts, in the Guercif area.

In the Rif Basin, the second episode of rifting began later mainly during the Toarcian and after a phase of relative tectonic quiescence (Favre et al., 1991; Elmi et al., 1998; Benest et al., 1999; Chotin et al., 2000; Gimeno-Vives et al., 2019; Fig. 16e). Nevertheless, the deposition of sedimentary breccias during the Early Jurassic (Favre, 1992) suggests a tectonic instability but without significant tectonic subsidence. The main phase of rifting, crowned by the exhumation of the Mesorif Gabbroic Complex along major detachments (Fig. 16f), occurred during Middle Jurassic times. The syn-rift configuration is well-preserved in the Senhadja Nappe (see a review in Gimeno-Vives et al., 2020b; Fig. 11). In the Mesorif, the second episode of Jurassic rifting is sealed by the "Ferrysh Fm" (Wildi, 1983), consisting 
of Upper Jurassic turbidites and interpreted as a post-rift stratigraphic succession. In the Intrarif (i.e. the distal part of the Tethys margin), this rifting was active until the end of the Jurassic, as demonstrated by mantle exhumation via hyper-extension associated to the occurrence of peridotites in the Beni Malek massif (Gimeno-Vives et al., 2019; Michard et al., 1992, 2007; Gimeno- Vives et al., 2020a; Fig. 16f), and followed by drifting during the Lower Cretaceous.

The organization is relatively similar for the "Pays des Horsts" (NE Morocco) and the Tlemcen area (NW Algeria; Fig. 1b). There, scarce tectonic activity is recognized during Early Jurassic. Rifting resumed during the Toarcian, with a relatively quiescent period during the Aalenian, followed by an important Bathonian-Bajocian tectonic activity and related deepening of the sedimentary environments (Fedan, 1988; Charrière, 1990; Benest et al., 1999; Chotin et al., 2000). A Kimmeridgian/Early Cretaceous extensional activity is also demonstrated in the "Pays des Horsts", with a global northward deepening towards the Maghrebian Tethys (Chotin et al., 2000). In addition, the possible Lower to Middle / Upper Jurassic extensional activity recorded below the Guercif Basin (Zizi, 2002) could be related to the same extension that is recorded in the Rif and the "Pays des Horsts" and Tlemcen area.

Therefore, looking at the scale of the entire Atlas and Rif systems, it appears that the Jurassic rifting developed firstly in a trend oriented NE-to ENE in the Central High Atlas, the Middle Atlas, the Tendrara Basin and the Sahara Atlas and was primarily associated to the opening of the Central Atlantic (Figs. 16d). At the end of the Toarcian, whereas oceanization began in the Central Atlantic and rifting stopped in the High Atlas, the continental rift jumped with a NE- and ENE oriented trend in the Rif Basin, "Pays des Horsts" and Tlemcen area, respectively (Fig. 16e). This led ultimately to mantle exhumation during the uppermost Jurassic in the Rif Basin, and to pulses of extension through Middle and Late Jurassic in the "Pays des Horsts", Tlemcen area and in the NE Middle Atlas (Fig. 16f). This rifting episode and the subsequent drifting accommodated the relative left-lateral transtensional displacement between Africa and Newfoundland-Iberia and the extensional settings ceased quickly after the Early Cretaceous. Drifting in the Maghrebian Tethys lasted up to the Campanian and the onset of the Africa-Eurasia convergence.

The Jurassic timespan can thus be observed as a nice example of how, due to tectonic inheritance, the far-field stresses and their orientations are being sampled by the different Moroccan and Algerian rifted segments. It is different from the Triassic rifting since the Jurassic geodynamic kinematics (i.e. the openings of the Central Atlantic Ocean and the Maghrebian Tethys) "activated" different segments of the weakened NW African lithosphere over which the extensional deformational was distributed. Instead, the Triassic rifting stage is characterized as a more "diffuse" extensional and thermal event during which the tensile stress due to the Pangaea disruption are widely distributed along the main 
inherited structural trends (see Figs. 3 and 16c), causing all the concerned areas to undergo rifting accompanied with important magmatism.

\subsection{A contrasted tectonic inversion}

In the NW Africa paleomargin, like in the whole Tethys realm, the tectonic inversion began by the Late Cretaceous (e.g. Frizon de Lamotte et al., 2011; Jolivet et al., 2015). However, this first event is poorly expressed in the Rif and Atlas (Froitzheim et al., 1988); as the major inversion occurred later during the Middle-Late Eocene and upper Miocene times (Frizon de Lamotte et al., 2000, 2008, and 2011; Leprêtre et al., 2018b; Gimeno-Vives et al., 2020b; Fig. 2).

In the Atlas system, along our NW-SE cross-section from the Rif Basin to the Sahara Atlas, the Mesozoic rift basins are globally inverted. The peculiar case of the Eastern High Atlas (Tamlelt area, Fig. 1b), an E-W segment joining the ENE-trending Central High Atlas and Sahara Atlas, must be discussed here. It does not correspond to a former basin but represents a Mesozoic structural high bounded by reverse faults since the Variscan orogeny. Therefore, in this case, the Cenozoic inversion directly reactivated Variscan structures, that strike E-W in this area (Houari and Hoepffner, 2003). By contrast, the Tendrara Basin, constituting the continuation of the Central High Atlas, is poorly inverted. The reasons explaining these differences in the structural evolution are not completely understood. However, the spacing imposed by the inversion of the Middle Atlas and the Eastern High Atlas could control the wavelength and the localization of the contractional deformation and the preservation of areas, like for example the Tendrara Basin being poorly affected by compressional deformations. In addition, the tectonic/ thermal inheritance of the Mesozoic rifting might also control the locus for the contractional deformation during the inversion of the rim basins (e.g. Gueydan et al., 2019). But in contrast to the Pyrenees, where rifting was directly followed by compression (Rosenbaum et al., 2002; Lagabrielle et al., 2010; Vacherat et al., 2014), in the Atlas system, the time gap between extension (ended by 145 $\mathrm{Ma}$ ) and subsequent compression (onset at $83 \mathrm{Ma}$ ) could be long enough for the thermal reequilibration and strengthening of the lithosphere.

North of the Atlas system, the geodynamic evolution of the Rif is dominated by the under-thrusting climax of the Maghrebian paleomargin below the Maghrebian Tethys during the Middle-Late Eocene (Leprêtre et al., 2018a; Gimeno-Vives et al., 2020b). During the Oligocene, the convergence between Africa and Europe was being accommodated along a new subduction located parallel to the northern margin of the Maghrebian Tethys. From the Middle/Late Miocene onwards, and by contrast, the deformation in the Rif has been dominated by the westward translation of the Alboran Domain (see a review in Gimeno-Vives et al., 2020b). In the Atlas domain instead, no significant deformation is recorded but the region was the site of a thermal uplift occurring along a stripe crossing Morocco from 
the Anti-Atlas to the eastern Rif and causing some dramatic sliding along the borders of the system (see Leprêtre et al., 2018b). The so-called "Morocco Hot Line", which is underlined by recent volcanism (see review in Missenard and Cadoux, 2012), partly explains the high elevation characterizing Morocco by comparison to Algeria or Tunisia (Missenard et al., 2006). Finally, by the late Miocene, a new contractional event is recorded in the whole area, leading to the reactivation of the Middle-Late Eocene structures.

\section{Conclusion}

The interpretation of subsurface data combined with field observations and detailed bibliographic revisions of several Mesozoic rim basins in NW Africa have shed new light on the factors that controlled the rift initiation, its development and the final accretion of oceanic crust in the Maghrebian Tethys. From this structural analysis, we suggest the following conclusions:

1. The Late Devonian-Early Carboniferous rift basins are of crucial importance for the tectonic evolution of NW Africa since the subsequent Moroccan Variscan Belt and Meso-Cenozoic deformation events directly resulted from the structural inheritance of these basins. Specifically, the pre-orogenic conditions, that allowed the accumulation of heat, facilitated the inversion of the former Paleozoic basins during the late Variscan Orogeny. Therefore, in addition to the structural control of the Paleozoic extensional faults, the thermal inheritance differently distributed along the Paleozoic basins and horsts influenced the mode in which the Variscan inversion took place in NW Africa.

2. The trends of the subsequent Mesozoic Atlas rift were strictly controlled by the structural inheritance of the Moroccan Variscan Belt. However, the rim basins analyzed in this study were indifferently developed over both former lower Paleozoic horsts and Lower Carboniferous rift basins. This may suggest that at the onset of the Mesozoic rifting period, the lithosphere was thermally reequilibrated, and the system was rejuvenated with more fertile lithospheric mantle (i.e. "mantle plume" effect). A possible pre-requisite for the subsequent development of the Triassic rifting and the future CAMP event.

3. At the scale of the entire NW Africa paleomargin, the Triassic rifting was widely distributed and controlled by the Variscan structures. The emplacement of large magmatic additions (related to the CAMP) within the continental crust at about $200 \mathrm{Ma}$ (and specifically the Mesorif Gabbroic complex in the Rif Basin) denotes an important thinning and weakening of the lithosphere. This process could be enhanced by crustal-scale faults inherited from previous Paleozoic and/or older deformation events acting as preferential conduits for the emplacement of magmatic bodies into the already weakened continental crust. 
4. After the CAMP event and until Bajocian times, rifting/spreading propagated from the northern part of the Central Atlantic Ocean domain north-eastward towards the incipient Maghrebian Tethys. Note again the role played by the tectonic/thermal inheritance on the localization of the new Tethyan oceanic domain along a pre-existent E-W transform fault accommodating the relative left-lateral transtensional displacement between Africa and Newfoundland-Iberia. Following the north-eastward propagation of the Jurassic rifting, extension in the Atlas system (Middle Atlas, the Central High Altas, Tendrara Basin and the Sahara Atlas) mainly occurred during middle to late Pliensbachian and was over by the Toarcian. However, in the Rif but also in the Pays des Horst, Tlemcen area and Guercif Basin, the extension climaxed during the Middle Jurassic with the exhumation of the Mesorif Grabbroic Complex along major low-angle extensional faults. By the Upper Jurassic, hyper-extension led to mantle exhumation in the distal part of the margin marking the onset of drifting in the Maghrebian Tethys. According to the Jurassic tectonic agenda of NW Africa, the deformation was sampled by the different Moroccan and Algerian rifted segments developed during Triassic times. This rifting period is different from the Triassic since the successive openings of the Central Atlantic Ocean and Maghrebian Tethys activated different segments of the weakened NW African continental crust where the extensional deformation was distributed.

5. Finally, the Alpine inversion of the rim basins in the NW African margin mainly affected the areas that underwent major stretching during the Mesozoic rifting phase. In addition, the spacing imposed by the inversion of the Middle Atlas and the Eastern High Atlas could control the wavelength and the localization of the contractional deformation and the preservation of areas, like for example the Tendrara Basin being poorly affected by compressional deformations.

\section{Declaration of Competing Interest}

The authors declare that they have no known competing financial interests or personal relationships that could have appeared to influence the work reported in this paper.

\section{Acknowledgments}

This work was funded by the Total Group and comes from the results of a M2 internship conducted by the first author at the same company. The authors wish to acknowledge an anonymous reviewer and the editor for their constructive and fruitful reviews. The views and conclusions contained in this article are solely those of the authors and should not be interpreted as necessarily representing the views or the official policies, either expressed or implied, of the Total Group.

\section{Appendix A. Supplementary data}




Supplementary data to this article can be found online at
https://doi.org/10.1016/i.earscirev 2021.103732
https://doi.org/10.1016/i.earscirev.2021.103732

\section{References}

Addi, Ait, 2006. The Dogger reef horizons of the Moroccan Central High Atlas: New data on their development. J. Afr. Earth Sci. 45, 162-172.

Aït Ouali, R., 1991. Le rifting des Monts des Ksour au Lias. Organisation du bassin, diagenèse des assises carbonatées, place dans les ouvertures mésozoiques au Maghreb. PhD Thesis. Univ. STHB Alger, p. 298.

Alberti, A., Castorina, F., Cendi, P., Comin-Chiaramonti, P., Gomes, C.B., 1999. Geochemical characteristics of cretaceous carbonatites from Angola. J. Afric. Earth Sci. 29 (4), 735-759.

Azil, A., Aït Ouali, R., 2017. Lithostratigraphy and geodynamic evolution of lower cretaceous sedimentary depocenter infilling, in Western Saharan Atlas (Algeria). Arab. J. Geosci. 10, 283. https://doi.org/10.1007/s12517-017-3068-z.

Bassoulet, J.P., 1973. Contribution à l'étude stratigraphique du Mésozoïque de l'atlas saharien occidental (Algérie). Thèse dès Sciences, Paris, 2 tomes, p. 497.

Baudelot, S., Charriere, A., Ouarhache, D., Sabaoui, A., 1990. Données palynologiques nouvelles concernant l'Ordovicien et le Trias-Lias du Moyen-Atlas (Maroc). Géologie Mediterranéenne, XVII (34), pp. 263-277.

Beauchamp, J., 1988. Triassic sedimentation and rifting in the High Atlas (Morocco). In: Mainspeizer, W. (Ed.), Triassic-Jurassic Rifting. Continental Breakup and the Origin of the Atlantic Ocean and Passive Margins. Elsevier, Amsterdam, pp. 477-497.

Benaouiss, N., Tourani, A., Bourquin, S., 2011. The Permian-Triassic transition and the beginning of the Mesozoic sedimentation in High Atlas of Marrakech and Argana basins, Morocco. In: 6 ème Réunion du Groupe Marocain du Permien et du Trias GMPT-6, May 2011, Tétouan, Morocco, p. 10.

Benest, M., Bensalah, M., Bouabdellah, H., Ouardas, T., 1999. La couverture mésozoïque et cénozoïque du domaine Tlemcénien (Avant pays Tellien d'Algérie occidentale): Stratigraphie, paléoenvironnement, dynamique sédimentaire et tecto-genèse alpine. Bulletin du Service Géologique de l'Algérie 10, 2. 
Bernini, M., Boccaletti, M., El Mokhtari, J., Gelati, R., laccarino, S., Moratti, G., Papani, G., 1992. Données stratigraphiques nouvelles sur le Miocéne supérieur du bassin de Taza-Guercif (Maroc nordoriental). Bull. Soc. Géol. France 63, 73-76.

Bernini, M., Boccaletti, M., Moratti, G., Papani, G., 2000. Structural development of the Taza-Guercif Basin as a constraint for the Middle Atlas Shear Zone tectonic evolution. Mar. Pet. Geol. 17, 343-357.

Bertrand, H., 1991. The Mesozoic tholeiitic Province of Northwest Africa: A volcanotectonic record of the early opening of Central Atlantic. In: Kampunzu, A.B., Lulab, R.T. (Eds.), Magmatism in Extensional Settings: The Phanerozoic African Plate. Springer, Berlin, Heidelberg, pp. 147-188.

Biari, Y., Klingelhoefer, F., Sahabi, M., Funck, T., Benabdellouahed, M., Schnabel, M., Reichert, C., Gutscher, M.-A., Bronner, A., Austin, J.A., 2017. Opening of the Central Atlantic Ocean: implications for geometric rifting and asymmetric initial seafloor spreading after continental breakup. Tectonics 36 , 1129-1150. https://doi.org/ 10.1002/2017TC004596,10.1016/jepsl.2013.02.024.

Boote, D.R.D., Clark-Lowes, D.D., Traut, M.W., 1998. Palaeozoic petroleum systems of North Africa. Geol. Soc. Lond. Spec. Publ. 132, 7-68. https://doi.org/10.1144/GSL. SP.1998.132.01.02.

Bouabdelli, M., 1989. Tectonique et sédimentation dans un bassin orogénique: le sillon viséen d'AzrouKhénifra (Est du Massif hercynien central du Maroc). Unpubl. Thesis (Thèse d’Etat) Univ. Louis Pasteur, Strasbourg, p. 270.

Bracène, R., 2002. Géodynamique du Nord de l'Algérie : Impact sur l'exploration pétrolière. PhD Thesis. Univ. Cergy-Pontoise. Bracène, R., Frizon de Lamotte, D., 2002. The origin of intraplate deformation in the Atlas system of western and Central Algeria: from Jurassic rifting to Cenozoic- Quaternary inversion. Tectonophysics 357 (1-4), 207-226. https://doi.org/ 10.1016/S0040-1951(02)00369-4.

Bracène, R., Bellahcene, A., Bekkouche, D., Mercier, E., Frizon de Lamotte, D., 1998. The thin-skinned style of the South Atlas Front in Central Algeria, in: Macgregor, D.S., Moody, R.T.J., Clark-Lowes, D.D. (Eds.), Petroleum Geology of North Africa. Geol. Soc. Spec. Publ. 133, 395-404.

Brun, J.P., 1999. Narrow rifts versus wide rifts: Inferences for the mechanics of rifting from laboratory experiments. Philosophical transactions of the Royal Society a: Mathematical. Phys. Eng. Sci. 357 (1753), 695-712. https://doi.org/10.1098/ rsta.1999.0349.

Buck, W.R., 1991. Modes of Continental Lithospheric Extension. J. Geophys. Res. 96, 20,161-20,178. https://doi.org/10.1029/91JB01485.

Burg, J.P., van den Driessche, J., Brun, J.P., 1994. Syn- to post-thickening extension in the Variscan Belt of Western Europe: modes and structural consequences. Géol. Fr. 3, 33-51. 
Burke, K., Dewey, J.F., 1973. Plume generated triple junctions: key indicators in applying plate tectonics to old rocks. J. Geol. 81, 406-433.

Burkhard, M., Caritg, S., Helg, U., Robert-Charrue, C., Soulaimani, A., 2006. Tectonics of the Anti-Atlas of Morocco. Compt. Rendus Geosci. 338, 11-24.

Chabou, M.C., Bertrand, H., Sebaï, A., 2010. Geochemistry of Moroccan evaporites in the setting of the North Atlantic Magmatic Province (CAMP) in south-western Algeria. J. Afr. Earth Sci. 58, 211-221.

Chalouan, A., Michard, A., El Kadiri, Kh., Negro, F., Frizon de Lamotte, D., Soto, J.I., Saddiqi, O., 2008. The Rif Belt. In: Michard, A., Saddiqi, O., Chalouan, A., Frizon de Lamotte, D. (Eds.), Continental Evolution: the Geology of Morocco. Lecture Notes in Earth Sciences, 116. Springer-Verlag, pp. 203302.

Charrière, A., 1990. Héritage hercynien et évolution géodynamique alpine d'une chaîne intracontinentale: le Moyen Atlas au SE de Fès (Maroc), Unpubl. Doct. Etat thesis, 589. Univ. PaulSabatier Toulouse.

Charrière, A., Haddoumi, H., 2016. Les “Couches rouges" continentales jurassico-crétacées des Atlas marocains (Moyen Atlas, Haut Atlas central et oriental): Bilan stratigraphique, paléogéographies successives et cadre géodynamique. Boletin Geologico y Minero 127 (2-3), 407-430. Chopin, F.,

Corsini, M., Schulmann, K., El Houicha, M., Ghienne, J.F., Edel, J.B., 2014. Tectonic evolution of the Rehamna metamorphic dome (Morocco) in the context of the Alleghanian-Variscan orogeny. Tectonics 33 (6), 1154-1177. https://doi.org/ 10.1002/2014TC003539.

Chotin, P., Ait Brahim, L., Tabyaoui, H., 2000. The southern Tethyan margin in Northeastern Morocco: sedimentary characteristics and tectonic control, in: Crasquin-Soleau, S., Barrier, E. (Eds.), Peri-Tethys Memoir 5: new data on Peri- Tethyan sedimentary basins. Mém. mus. Natn. Hist. Nat. 182, 107-128.

Choubert, G., Faure-Muret, A., 1960-62. Evolution du domaine atlasique marocain depuis les temps paléozoïques, in: Livre à la mémoire du Professeur Paul Fallot. Soc. Géol. Fr., Mem. h.- s 447-527.

Clerc, C., Lahfid, A., Monié, P., Lagabrielle, Y., Chopin, C., Poujol, M., De St Blanquat, M., 2015. Hightemperature metamorphism during extreme thinning of the continental crust: a reappraisal of the North Pyrenean passive paleomargin. Solid Earth 6, 643-668. https://doi.org/10.5194/se-6-643-2015.

Colletta, B., 1977. Evolution néotectonique de la partie méridionale du bassin de Guercif (Maroc oriental). Université Scientifique et Médicale de Grenoble. 
Courel, L., Ait Salem, H., Benaouiss, N., Et-Touhami, M., Fekirine, B., Oujidi, M., Soussi, M., Tourani, A., 2003. Mid-Triassic to early Liassic clastic/evaporitic deposits over the Maghreb Platform. Palaeogeogr. Palaeoclimatol. Palaeoecol. 196, 157-176.

Craig, J., Rizzi, C., Said, F., Thusu, B., Luning, S., Asbali, A.I., Keeley, M.L., Bell, J.F., Durham, M.J., Eales, M.H., 2008. Structural styles and prospectivity in the Precambrian and Palaeozoic hydrocarbon systems of North Africa, Geol. East Libya 4, 51-122. Davison, I., 2005. Central Atlantic margin of north West Africa: Geology and hydrocarbon potential (Morocco to Guinea). J. Afr. Earth Sci. 43, 254-274. https:// doi.org/10.1016/j.jafrearsci.2005.07.018.

Delchini, S., 2018. Etude tectono-thermique d'un segment orogénique varisque à histoire géologique complexe: analyse structurale, géochronologique et thermique du massif des Jebilet, de l'extension à la compression. PhD Thesis. Université d'Orléans, Orléans (263 p).

Delchini, S., Lahfid, A., Lacroix, B., Baudin, T., Hoepffner, C., Guerrot, C., Lach, P., Saddiqi, O., Ramboz, C., 2018. The geological evolution of the Variscan Jebilet Massif, Morocco, inferred from new structural and geochronological analyses. Tectonics 37, 4470-4493.

Delfaud, J., 1974. Les grands traits de la paléogéographie de l'Algérie septentrionale durant le Jurassique supérieur et le Crétacé inférieur. CR somm. Soc. géol. France 6, 167-168.

Delfaud, J., 1986. Organisation scalaire des événements sédimentaires majeurs autour de la Mésogée durant le Jurassique et le Crétacé. Conséquences sur les associations biologiques. Bull. Cent. Rech. Explor. Prod. Elf-Aquitaine, Pau 10 (2), 509-535.

Dercourt, J., Gaetani, M., Vrielynck, B., Barrier, E., Biju-Duval, B., Brunet, M.F., Cadet, J. P., Crasquin, S., Sandulescu, M., 2000. Peri-Tethys Atlas; Palaeogeographical Maps; Explanatory Notes. Commission for the Geologic map of the World, Paris, France.

Du Dresnay, R., 1987. Jurassic development of the region of the Atlas Mountains of Morocco: Chronology, sedimentation and structural significance. In: Cornelius, C.D., Jarnaz, M., Lehman, E.P. (Eds.), Geology and Culture of Morocco. Earth Sciences Society of Lybia, pp. 77-99. Du Dresnay, R., 1988. Répartition des dépôts carbonatés du Lias inférieur et moyen le long de la côte atlantique du Maroc: conséquences sur la paléogéographie de l'Atlantique naissant. J. Afr. Earth Sci. 7, 385-396.

Durand-Delga, M., Fontboté, J.M., 1980. Le cadre structural de la Méditerranée occidentale. In 260 Congrès Géol. Intern. Paris, Colloque no. 5, Les chaines alpines issues de la Téthys. Durand-Delga, M., Hottinger, L., Marcais, J., Mattauer, M., Milliard, Y., Suter, G., 1960- 1962. Donnés actuelles sur la structure du Rif. Mdm. h. s. Soc. géol. Fr., Livre mém. Prof. Fallot 1, 399-422. 
Duretz, T., Petri, B., Mohn, G., Schmalholz, S.M., Schenker, F.L., Müntener, O., 2016. The importance of structural softening for the evolution and architecture of passive margins. Sci. Rep. 6, e38704 https://doi.org/10.1038/srep38704.

Edel, J.B., Schulmann, K., Lexa, O., Lardeaux, J.M., 2018. Late Palaeozoic palaeomagnetic and tectonic constraints for amalgamation of Pangea supercontinent in the European Variscan belt. Earth Sci. Rev. 177, 589-612. https://doi.org/ 10.1016/J. EARSCIREV.2017.12.007.

El Arabi, H., Charrière, A., Sabaoui, A., Ouahhabi, B., Kerchaoui, S., Boutakiout, M., Laadila, M., 1999. Le Toarcien et l'Aalénien dans le nord du Moyen-Atlas plissé (Maroc): diversité de l'enregistrement sédimentaire et reconstitution du contexte paléogéographique. Bull. Soc. Géol. France 170 (5), 629641.

El Arabi, H., Ouhhabi, B., Charrière, A., 2001. Les séries du Toarcien-Aalénien du SW du Moyen- Atlas (Maroc): précisions stratigraphiques et signification paléogéographique. Bull. Soc. géol. Fr. 172, $723-$ 736.

El Arabi, E.H., Ferrandini, J., Essamoud, R., 2003. Triassic stratigraphy and structural evolution of a rift basin: the Eç Cour basin, High Atlas of Marrakech, Morocco. J. Afr. Earth Sci. 36 (1-2), 29-39.

El Hachimi, H., Youbi, N., Madeira, J., Marzoli, A., Mata, J., Bertrand, H., Martins, L., 2020. Physical volcanology and emplacement mechanism of the Central Atlantic Magmatic Province (CAMP) lava flows from the Central High Atlas, Morocco. Comptes Rendus. Géoscience 0 (0), 1-18. https://doi.org/10.5802/crgeos.7.

El Hadi, H., Simancas Cabrera, F., Tahiri, A., Gonz'alez Lodeiro, F., Azor Pérez, A., Martínez Poyatos, D.J., 2006. Comparative review of the Variscan granitoids of Morocco and Iberia: proposal of a broad zonation. Geodin. Acta 19, 103-116.

El Hammichi, F., Elmi, S., Faure-Muret, A., Benshili, K., 2002. Une plate-forme en distension, témoin de phases pré-accrétion téthysienne en Afrique du Nord pendant le Toarcien-Aalénien, synclinal Iguer Awragh-Afennourir, Moyen Atlas occidental, Maroc. C. R. Geosci. 334 (13), 1003-1010.

El Hassani, A., 1994. Stratigraphie et environnement sédimentaire du Bloc des Sehoul. In: El Hassani, A., Piqué, A., Tahiri, A. (Eds.), Le Massif Central Marocain et la Meseta orientale. Bull. Inst. Sci. Rabat, vol. spéc, 18, pp. 3-9. El Kamel, F., El Hassani, A., 2006. étapes de la structuration et de la sédimentation du bassin viséen de Mechra ben Abbou (Meseta occidentale marocaine). Geodiversitas 28 (4), 529-542. 
Eley, R., Grütter, H., Louw, A., Tunguno, C., Twidale, J., 2008. Exploration geology of the Luxinga kimberlite cluster (Angola) with evidence supporting the presence of kimberlite lava. In: 9th International Kimberlite Conference Extended Abstract No. 9IKC-A-00166. https://doi.org/10.29173/ikc3410.

Ellouz, N., Patriat, M., Gaulier, J.-M., Bouatmani, R., Sabounji, S., 2003. From rifting to Alpine inversion: Mesozoic and Cenozoic subsidence history of some Moroccan basins. Sediment. Geol. 156, 185-212.

Elmi, S., 1996. Stratigraphic correlations of the Main Jurassic events in the Western Mediterranean Tethys (Western Algeria and Eastern Morocco). Geology Research Forum 1-2, 343-358.

Elmi, S., Alméras, V., Ameur, M., Bassoulet, J.-P., Boutakiout, M., Benhamou, M., Marok, A., Mekahli, L., Mekkaoui, A., Mouterde, R., 1998. Stratigraphic and palaeogeographic survey of the lower and Middle Jurassic along a north-south transect in western Algeria, in: Crasquin-Soleau, S., Barrier, E. (Eds.), Peri-Tethys Memoir 4. Epicratonic basins of Peri-Tethyan platforms, Mémoires du Muséum national d'Histoire naturelle de Paris 179, 145-211.

Eschard, R., Braik, F., Bekkouche, D., Ben Rahuma, M., Desaubliaux, G., Deschamps, R., Proust, N., 2010. Paleohighs: Their influence on the North African Palaeozoic petroleum systems. In: Vining, B.A., Pickering, S.C. (Eds.), Petroleum Geology: From Mature Basins Fo New Frontiers - Proceedings of the 7th Petroleum Geology Conference. Geological Society, London, pp. 707-724. https://doi.org/10.1144/ 0070707.

Et-Touhami, M., 2000. Lithostratigraphy and depositional environments of lower mesozoic evaporites and associated red beds, Khemisset Basin, northwestern Morocco. In: Bachmann, G., Lerche, I. (Eds.), Epicontinental Triassic, vol. 2. Zentralblatt fur Geologic und Palaontologie, VIII, pp. 1217-1241.

Fabre, J., 2005. Géologie du Sahara occidental et central. Tervuren Afric. Geosci. Coll. 108, 572.

Favre, P., 1992. Géologie des massifs calcaires situés au front sud de l'unité de Ketama. Thesis. Dep. Giol. Paleontol. Univ, Genève.

Favre, P., Stampfli, G.M., 1992. From rifting to passive margin: the examples of the Red Sea, Central Atlantic and Alpine Tethys. Tectonophysics 215 (1-2), 69-97. https:// doi.org/10.1016/00401951(92)90075-H.

Favre, P., Stampfli, G., Wildi, W., 1991. Jurassic sedimentary record and tectonic evolution of the northwestern corner of Africa. Palaeogeogr. Palaeoclimatol. Palaeoecol. 87 (1-4), 53-73. https://doi.org/10.1016/0031-0182(91)90130-J. 
Fedan, B., 1977. étude structural d'une portion de l'accident nord moyen Atlasique (Moyen Atlas central de Boulemane, Maroc). Bulletin de I'Institut Scientifique, Rabat 2, 87-96.

Fedan, B., 1988. Evolution géodynamique d'un basin intraplaque sur décrochements: Le Moyen Atlas (Maroc) durant le Méso-cénozoique. Thèse de Doctorat Es Sciences de Rabat. Université Mohamed V, Rabat, p. 338.

Fernandez, O., 2019. The Jurassic evolution of the Africa-Iberia conjugate margin and its implications on the evolution of the Atlantic-Tethys triple junction. Tectonophysics 750, 379-393. https://doi.org/10.1016/j.tecto.2018.12.006.

Frizon De Lamotte, D., 1985. La structure du Rif oriental (Maroc). Rôle de la tectonique longitudinale et importance des fluides. These Doct. Etat, Univ. P. et M. Curie, Paris VI. Sci. Terre. (85-03).

Frizon de Lamotte, D., Saint Bezar, B., Bracène, R., Mercier, E., 2000. The two main steps of the Atlas building and geodynamics of the western Mediterranean. Tectonics 19 (4), 740-761.

Frizon de Lamotte, D., Zizi, M., Missenard, Y., Hafid, M., Azzouzi, M.E., Maury, R.C., Charrière, A., Taki, Z., Benammi, M., Michard, A., 2008. The Rif Belt Continental Evolution. In: Michard, A., et al. (Eds.), The Geology of Morocco, 116. Springer, Berlin/Heidelberg, pp. 133-203.

Frizon de Lamotte, D., Leturmy, P., Missenard, Y., Khomsi, S., Ruiz, G., Saddiqi, O., Guillocheau, F., Michard, A., 2009. Mesozoic and Cenozoic vertical movements in the Atlas system (Algeria, Morocco, Tunisia): an overview. Tectonophysics 475 (1), 9-28.

Frizon de Lamotte, D., Raulin, C., Mouchot, N., Wrobel-Daveau, J.C., Blanpied, C., Ringenbach, J.C., 2011. The southernmost margin of the Tethys realm during the Mesozoic and Cenozoic: initial geometry and timing of the inversion processes. Tectonics 30, TC3002. https://doi.org/10.1029/2010TC002691.

Frizon de Lamotte, D., Tavakoli-Shirazi, S., Leturmy, P., Averbuch, O., Mouchot, N., Raulin, C., Leparmentier, F., Blanpied, C., Ringenbach, J.C., 2013. Evidence for late Devonian vertical movements and extensional deformation in northern Africa and Arabia: Integration in the geodynamics of the Devonian world. Tectonics 32, 107-122. https://doi.org/10.1002/tect.20007.

Frizon de Lamotte, D., Fourdan, B., Leleu, S., Leparmentier, F., de Clarens, P., 2015. Style of rifting and the stages of Pangea breakup. Tectonics 34, 1009-1029. https://doi. org/10.1002/2014TC003760.

Froitzheim, N., Stets, N., Wurster, P., 1988. Aspects of western High Atlas tectonics. In: Jacobshagen, V. (Ed.), The Atlas System of Morocco. Springer, New York, pp. 219-244. 
Galmier, D., 1972a. Photogéologie de la region d’Aïn Sefra (Algérie). Bull. Serv. Geol. Algérie 42, 1-189.

Galmier, D., 1972b. Carte géologique de Forthassa el Rharbia, E-13. Bull. Serv. Geol. Algérie 42.

Ghorbal, B., Bertotti, G., Foeken, J., Andriessen, P., 2008. Unexpected Jurassic to Neogene vertical movements in 'stablé parts of NW Africa revealed by low temperature geochronology. Terra Nova 20 (5), 355-363.

Gimeno-Vives, O., Mohn, G., Bosse, V., Haissen, F., Zaghloul, M.N., Atouabat, A., Frizon de Lamotte, D., 2019. The Mesozoic margin of the Maghrebian Tethys in the Rif Belt (Morocco): evidence for Polyphase Rifting and Related Magmatic activity. Tectonics 38 (8), 2894-2918. https://doi.org/10.1029/2019TC005508.

Gimeno-Vives, O., Mohn, G., Bosse, V., Haissen, F., Zaghloul, M.N., Atouabat, A., Frizon de Lamotte, D., 2020a. Reply to comment by Michard et al. on The Mesozoic Margin of the Maghrebian Tethys in the Rif Belt (Morocco): Evidence for Polyphase Rifting and Related Magmatic Activity. Tectonics 39 (4). https://doi.org/10.1029/ 2020TC006165.

Gimeno-Vives, O., Frizon de Lamotte, D., Leprêtre, R., Haissen, F., Atouabat, A., Mohn, G., 2020b. The structure of the Central-Eastern External Rif (Morocco); Poly-phased deformation and role of the under-thrusting of the North-West African paleo-margin. Earth-Science Reviews. https://doi.org/10.1016/i.meegid.2020.104265.

Graham, J., Sevastopulo, G.D., 2007. Preface: Mississipian platform and basin succession in the Todrha Valley (northeastern Anti-Atlas), Southern Morocco. Geol. J. 43 https://doi.org/10.1002/gi.1095.

Gueydan, F., Précigout, J., 2014. Role of ductile strain localization in the lithospheric mantle on continental rifting. EGU General Assembly 2014, Apr 2014, Vienne, Austria (1 page).

Gueydan, F., Morency, C., Brun, J.-P., 2008. Continental rifting as a function of lithosphere mantle strength. Tectonophysics 460 (1-4), 83-93.

Gueydan, F., Mazzotti, S., Tiberi, C., Cavin, R., Villase nor, A., 2019. Western Mediterranean Subcontinental Mantle Emplacement by Continental margin Obduction. Tectonics 38 (6), 2142-2157. https://doi.org/10.1029/2018TC005058.

Haddoumi, H., Charrière, A., Andreu, B., Mojon, P.O., 2008. Les depots continentaux du Jurassique moyen au Cretace inferieur dans le Haut-Atlas oriental (Maroc): Paleoenvironnements successifs et signification paleogeographique. Carnets de Geologie - Notebooks on Geology. http://paleopolis.rediris.es/cg/. 
Hafid, M., 2000. Triassic-early Liassic extensional systems and their Tertiary inversion, Essaouira Basin (Morocco). Mar. Pet. Geol. 17 (3), 409-429. https://doi.org/ 10.1016/S0264-8172(98)00081-6.

Hafid, M., Zizi, M., Ait Salem, A., Bally, A.W., 2006. Structural styles of the western onshore and offshore termination of the High Atlas, Morocco. Compt. Rendus Geosci. 338, 50-64.

Haissen, F., Zaghloul, M. N., Dilek, Y., Gimeno-Vives, O., Mohn, G., Cambeses, A., Frizon de Lamotte, D., Bosse, V., 2021. Geochemistry and Petrogenesis of Lower Jurassic Mafic Rock Suites in the External Rif Belt, and Chemical Geodynamics of the Central Atlantic Magmatic Province (CAMP) in Northwest Morocco. The Journal of Geology, 129(5).

Hoepffner, C., 1978. Le massif paléozoique du Tazekka (Maroc); analyse des déformations liées à un linéament tectonique. In: Sciences Géologiques. Bulletin, tome 31, n`1. Analyse tectonique et géologie structurale, pp. 33-44. https://doi.org/ 10.3406/sgeol.1978.1531.

Hoepffner, C., 1981. Le complexe volcano-sédimentaire d’^age carbonifère dans le massif du Tazekka; sa place dans l'évolution hercynienne de la Meseta marocaine orientale. Sci. Geol. Bull. 34 (2), 97-106. Hoepffner, C., 1987. La tectonique hercynienne dans l'est du Maroc. PhD Thesis. Univ. Louis Pasteur, Strasbourg (pp.280).

Hoepffner, C., Soulaimani, A., Piqué, A., 2005. The Moroccan Hercynides. J. Afr. Earth Sci. 43, 144-165. Hoepffner, C., Houari, M.R., Bouabdelli, M., 2006. Tectonics of the North African Variscides (Morocco, Western Algeria), an outline, in: Frizon de Lamotte, D., Saddiqi, O., Michard, A. (Eds.), recent Developments on the Maghreb Geodynamics. C. R. Geoscience 338, 25-40.

Hollard, H., 1967. Le Dévonien du Maroc et du Sahara nord-occidental. In: Oswald, D.H. (Ed.), International Symposium on the Devonian System, Volume 1: Calgary, Alberta Society of Petroleum Geology, pp. 203-244.

Hollard, H., Michard, A., Jenny, P., Hoepffner, C., Willefert, S., 1982. Stratigraphie du Primaire de Mechra ben Abbou. In: Michard, A. (Ed.), Le massif paléozoïque des Rehamna (Maroc). Stratigraphie, tectonique et pétrogenèse d'un segment de la chaîne varisque. Notes Mém. Serv. Géol. Maroc, 303, pp. 13-34.

Hopper, J.R., Buck, W.R., 1996. The effect of lower crustal flow on continental extension and passive margin formation. J. Geophys. Res. Solid Earth 101, 20175-20194. https://doi.org/10.1029/96JB01644. 
Houari, M.-R., Hoepffner, C., 2003. Late Carboniferous dextral wrench- dominated transpression along the North African craton margin (Eastern High-Atlas, Morocco). J. African Earth Sci. 37, 11-24.

Huismans, R.S., Podladchikov, Y.Y., Cloetingh, S., 2001. Transition from passive to active rifting: Relative importance of asthenospheric doming and passive extension of the lithosphere. J. Geophys. Res. 106 (B6), 11271-11291. https://doi.org/ 10.1029/2000JB900424.

Jaillard, E., Bouillin, J.P., Ouali, J., Dumont, T., Latil, J.L., Chihaoui, A., 2017. Albian salt-tectonics in Central Tunisia: Evidences for an Atlantic-type passive margin. J. Afr. Earth Sci. 135, 220-234. https://doi.org/10.1016/j.jafrearsci.2017.09.009.

Jelsma, H.A., McCourt, S., Perritt, S.H., Armstrong, R.A., 2018. The Geology and Evolution of the Angolan Shield, Congo Craton. In: Siegesmund, S., Basei, M., Oyhantçabal, P., Oriolo, S. (Eds.), Geology of Southwest Gondwana. Regional Geology Reviews. Springer, Cham. https://doi.org/10.1007/978-3319-68920-3 9.

Jolivet, L., Faccenna, C., Agard, P., de Lamotte, D.F., Menant, A., Sternai, P., Guillocheau, F., 2015. NeoTethys geodynamics and mantle convection: from extension to compression in Africa and a conceptual model for obduction. Can. J. Earth Sci. 53 (11), 1190-1204. https://doi.org/10.1139/cjes-2015-0118.

Joussiaume, R., Malaval, M., Razin, P., Grelaud, C., Messager, G., Martin-Martin, J.D., Saura, E., Moragas, M., Verges, J., Hunt, D., 2014. Characterization of Syn-Diapiric Jurassic Sedimentation in the Taghia and Tazoult areas, Central High Atlas, Morocco. In: 19th International Sedimentological Congress. International Association of Sedimentologist, Geneva, Switzerland.

Kacemi, A., 2013. Evolution lithostructurale des Monts des Ksours (Atlas Saharien, Algérie) au cours du Trias et du Jurassique: Géodynamique, typologie du basin et télédétection. PhD thesis. Univ. Abou Bekr Belkaid, Tlemcen, p. 249.

Kazi-Tani, N., 1986. Evolution geodynamique de la bordure nord africaine: le domaine intraplaque nord algérien, approche sequentielle. These sd. Univ. Pau 2 (871 pp).

Khain, V.Y., 1992. The role of rifting in the evolution of the Earth's crust. Tectonophysics 215 (1-2), 17. https://doi.org/10.1016/0040-1951(92)90071-D.

Khomsi, S., Bédir, M., Soussi, M., Ben Jemia, M.G., Ben Ismail-Lattrache, K., 2006. Mise en évidence en subsurface d'événements compressifs Eocène moyen-supérieur en Tunisie orientale (Sahel): Généralité de la phase atlasique en Afrique du Nord. Compt. Rendus Geosci. 338, 41-49. https://doi.org/10.1016/j.crte.2005.11.001. 
Khomsi, S., Ben Jemia, M.G., Frizon de Lamotte, D., Maherssi, C., Echihi, O., Mezni, R., 2009. An overview of the late Cretaceous-Eocene positive inversions and Oligo- Miocene subsidence events in the foreland of the Tunisian Atlas: Structural style and implications for the tectonic agenda of the Maghrebian Atlas system. Tectonophysics 475, 38-58. https://doi.org/10.1016/i.tecto.2009.02.027.

Klitgord, K.D., Schouten, H., 1986. Plate kinematics of the central Atlantic. In: Vogt, P.R., Tucholke, B.E. (Eds.), The Geology of North America, the Western North Atlantic Region M. Geological Society of America, pp. 351-378.

Kneller, E.A., Johson, C.A., Karner, G.D., Einhorn, J., Queffelec, T.A., 2012. Inverse methods for modeling non-rigid plate kinematics: Application to mesozoic plate reconstructions of the central Atlantic. Comput. Geosci. 49, 217-230.

Knight, K.B., Nomade, S., Renne, P.R., Marzoli, A., Bertrand, H., Youbi, N., 2004. The Central Atlantic magmatic province at the Triassic-Jurassic boundary: paleomagnetic and 40Ar/30Ar evidence from Morocco for brief, episodic volcanism. Earth Planet. Sci. Lett. 228 (1/2), 143-160.

Korsch, R.J., Totterdell, J.M., Cathro, D.L., Nicoll, M.G., 2009. Early Permian East Australian Rift System. Aust. J. Earth Sci. 56 (3), 381-400.

Kusznir, N.J., Karner, G.D., Egan, S., 1987. Geometric, thermal and isostatic consequences of detachments in continental lithosphere extension and basin formation, in: Beaumont, C., Tankard, A. J., (Eds.). Sedimentary basins and basin-forming mechanisms - CSPG Memoir 12, 185-203.

Labails, C., Olivet, J.-L., Aslanian, D., Roest, W.R., 2010. An alternative early opening scenario for the Central Atlantic Ocean. Earth Planet. Sci. Lett. 297, 355-368.

Lachkar, G., Ouarrache, D., Charrière, A., 2000. Nouvelles données palynologiques sur les formations sédimentaires associées aux basanites triasiques du Moyen Atlas et de la Haute Moulouya (Maroc). Rev. Micropaleontol. 43, 281-299.

Lacoste, J., 1934. Etudes Geologiques dans le Rif meridional. Notes et Mémoires du Service Géologique $31,1-660$.

Lagabrielle, Y., Labaume, P., de Saint Blanquat, M., 2010. Mantle exhumation, crustal denudation, and gravity tectonics during cretaceous rifting in the Pyrenean realm (SW Europe): insights from the geological setting of the Iherzolite bodies. Tectonics 29, TC4012. https://doi.org/10.1029/2009TC002588.

Lahfid, A., Baidder, L., Ouanaimi, H., Soulaimani, A., Hoepffner, C., Farah, A., Michard, A., 2019. From extension to compression: high geothermal gradient during the earliest Variscan phase of the 
Moroccan Meseta; a first structural and RSCM thermometric study. Eur. J. Mineral. 31 (4), 695-713. https://doi.org/10.1127/ejm/ 2019/0031-2882.

Laville, E., 1977. L'évolution sédimentaire et tectonique de la couverture jurassique de la region d'Immouzzer de Marmoucha (Moyen Atlas - Maroc). Bull. Soc. Géol. France XIX (5), 1151-1158.

Laville, E., Charroud, A., Fedan, B., Charroud, M., Piqué, A., 1995. Inversion négative et rifting atlasique: le bassin triasique de Kerrouchkne (Moyen Atlas, Maroc). Bull. Soc. Geol. Fr. 116, 364-374.

Leleu, S., Hartley, A.J., 2010. Controls on the stratigraphic development of the Triassic Fundy Basin, Nova Scotia: implications for the tectonostratigraphic evolution of Triassic Atlantic rift basins. J. Geol. Soc. 167 (3), 437-454. https://doi.org/10.1144/ 0016-76492009-092.

Leleu, S., Hartley, A.J., van Oosterhout, C., Kennan, L., Ruckwied, K., Gerdes, K., 2016. Structural, stratigraphic and sedimentological characterization of a wide rift system: the Triassic rift system of the Central Atlantic Domain. Earth Sci. Rev. 158, 89-124. https://doi.org/10.1016/j.earscirev. 2016.03.008. Leprêtre, R., Missenard, Y., Barbarand, J., Gautheron, C., Saddiqi, O., Pinna-Jamme, R., 2015. Postrift history of the eastern Central Atlantic passive margin: Insights from the Saharan region of South Morocco: Postrift Evolution Moroccan margin. J. Geophys. Res. Solid Earth 120 (6), 4645-4666. https://doi.org/10.1002/ 2014JB011549.

Leprêtre, R., Frizon De Lamotte, D., Combier, V., Gimeno-Vives, O., Mohn, G., Eschard, R., 2018a. The Tell-Rif orogenic system (Morocco, Algeria, Tunisia) and the structural heritage of the southern Tethys margin. BSGF - Earth Sciences Bulletin 189 (10). https://doi.org/10.1051/bsgf/2018009.

Leprêtre, R., Missenard, Y., Jouvie, I., Barbarand, J., Saddiqi, O., 2018b. Polyphased Inversions of an Intracontinental Rift: Case Study of the Marrakech High Atlas, Morocco. Tectonics 37, 818-841. https://doi.org/10.1002/2017tc004693.

Lithgow-Bertelloni, C., Richards, M.A., 1998. The dynamics of Cenozoic and Mesozoic plate motions. Rev. Geophys. 36 (1), 27-78. https://doi.org/10.1029/97RG02282.

Lorenz, J., 1976. Triassic sediments and basin structure of the Kerrouchen basin, central Morrocco. J. Sediment. Petrol. 46 (4), 897-905.

Lorenz, J., 1988. Synthesis of late Paleozoic and Triassic redbed sedimentation in Morocco. In: Jacobshagen, V. (Ed.), The Atlas System of Morocco, Lecture Notes in Earth Sciences, vol. 15. SpringerVerlag, Berlin, pp. 139-168. 
Marzoli, A., Renne, P.R., Piccirillo, E.M., Ernesto, M., Bellieni, G., De Min, A., 1999. Extensive 200 million-year-old continental flood basalts of the Central Atlantic Magmatic Province. Science 284, 616618. https://doi.org/10.1126/ science.284.5414.616.

Marzoli, A., Bertrand, H., Knight, K.B., Cirilli, S., Buratti, N., Vérati, C., Bellieni, G., 2004. Synchrony of the Central Atlantic magmatic province and the Triassic-Jurassic boundary climatic and biotic crisis. Geology 32 (11), 973-976. https://doi.org/ 10.1130/G20652.1.

McKenzie, D., 1978. Some remarks on the development of sedimentary basins. Earth Planet. Sci. Lett. 40 (1), 25-32. https://doi.org/10.1016/0012-821X(78)90071-7.

Meddah, A., Bertrand, H., Elmi, S., 2007. La province magmatique de l'Atlantique central dans le bassin des Ksour (Atlas Saharien, Algérie). Compt. Rendus Geosci. 339, 24-30.

Meddah, A., Bertrand, H., Seddiki, A., Tabeliouna, M., 2017. The Triassic-Liassic volcanic sequence and rift evolution in the Saharan Atlas basins (Algeria). Eastward vanishing of the Central Atlantic magmatic province. Geol. Acta 15 (1), 11-23.

Medioni, R., 1980. Mise au point stratigraphique sur les terrains carbonifères de la bordure septentrionale des hauts plateaux marocains (Massif de Debdou, boutonnières de Lalla Mimouna et du Mekam). Notes Serv. géol. Maroc 41 (285), 25-37.

Mekahli, L., 1998. Evolution des monts des Ksour (Algérie) de l'Hettangien au Bajocien : Biostratigraphie, sédimentologie, paléogéographie et stratigraphie séquentielle. Documents des laboratoires de géologie, Lyon 147, 319.

Merle, O., 2011. A simple continental rift classification. Tectonophysics 513, 88-95.

Michard, A., Feinberg, H., Elazzab, D., Bouy-Baouene, M., Saddiqi, O., 1992. A serpentinite ridge in a collisional paleomargin setting. The Beni Malek massif, External Rif, Morocco. Earth and Planetary Science Letters 113, 435-442. https:// doi.org/10.1016/0012-821X(92)90144-K.

Michard, A., Negro, F., Frizon de Lamotte, D., Saddiqi, O., 2007. Serpentinite slivers and metamorphism in the External Maghrebides: arguments for an intracontinental suture in the African paleomargin (Morocco, Algeria). Rev. Soc. Geol. España 20 (3-4), 173-185.

Michard, A., Frizon de Lamotte, D., Saddiqi, O., Chalouan, A., 2008. An outline of the geology of Morocco. In: Michard, A., Saddiqi, O., Chalouan, A., Frizon de Lamotte, D. (Eds.), Continental Evolution: The Geology of Morocco. Lecture Notes in Earth Sciences. Springer-Verlag, Berlin Heidelberg, pp. 131. 
Michard, A., Saddiqi, O., Chalouan, A., Chabou, M.C., Lach, P., Rossi, P., et al., 2020. Comment on "The Mesozoic margin of the Maghrebian Tethys in the Rif Belt (Morocco): Evidence for polyphase rifting and related magmatic activity" by Gimeno-Vives et al. Tectonics 39. https://doi.org/10.1029/2019TC006004.

Michard, A., Soulaimani, A., Hoepffner, C., Ouanaimi, H., Baidder, L., Rjimati, E.C., Saddiqi, O., 2010. The South-Western Branch of the Variscan Belt: evidence from Morocco. Tectonophysics 492, 1-24. https://doi.org/10.1016/j.tecto.2010.05.021.

Missenard, Y., Cadoux, A., 2012. Can Moroccan Atlas lithospheric thinning and volcanism be induced by Edge-Driven Convection? Terra Nova 24 (1), 27-33. https://doi.org/10.1111/j.13653121.2011.01033.x.

Missenard, Y., Zeyen, H., Frizon de Lamotte, D., Leturmy, P., Petit, C., Sébrier, M., Saddiqi, O., 2006. Crustal versus asthenospheric origin of relief of the Atlas Mountains of Morocco. J. Geophys. Res. 111, B3. https://doi.org/10.1029/2005JB003708.

Moragas, M., Vergés, J., Saura, E., Martín-Martín, J.D., Messager, G., Merino-Tomé, et al., 2016. Jurassic rifting to post-rift subsidence analysis in the Central High Atlas and its relation to salt diapirism. Basin Res. 30, 336-362. https://doi.org/10.1111/ bre.12223.

Moragas, M., Vergés, J., Nalpas, T., Saura, E., Martín-Martín, J.D., Messager, G., Hunt, D. W., 2017. The impact of syn- and post-extension prograding sedimentation on the development of salt-related rift basins and their inversion: Clues from analogue modelling. Mar. Pet. Geol. 88, 985-1003. https://doi.org/10.1016/j. marpetgeo.2017.10.001.

Morin, P., 1973. L'accident de Bsabis-Tazekka, un linéament majeur de la tectonique hercynienne du Maroc (Ouest de Taza). C.R. somm. Soc. géol. Fr. 64-67.

Nomade, S., Knight, K.B., Beutel, E., Renne, P.R., Verati, C., Feraud, G., Marzoli, A., Youbi, N., Bertrand, H., 2007. Chronology of the Central Atlantic Magmatic Province: Implications for the Central Atlantic rifting processes and the Triassic- Jurassic biotic crisis. Palaeogeogr. Palaeoclimatol. Palaeoecol. 244, 326-344. https://doi.org/10.1016/j.palaeo.2006.06.034.

Oftedal, B.T., Andresen, A., Müller, R., 2005. Early Triassic syn-rift sedimentation at hold with Hope, Northeast Greenland, in: Onshore-Offshore Relationships on the North Atlantic margin, NPF Spec. Geological Survey of Norway. Trondheim. Publ. 12, 191-206.

Olsen, P.E., Kent, D.V., Et-Touhami, M., Puffer, J., 2003. Cyclo-, Magneto-, and Bio-stratigraphic constraints on the duration of the CAMP event and its relationship to the Triassic-Jurassic boundary. 
In: Hames, W.E., McHone, J.G., Renne, P.R., Ruppel, C.R. (Eds.), The Central Atlantic Magmatic Province; Insights from Fragments of Pangea, Geophysical Monograph, 136. American Geophysical Union, Washington, pp. 7-32.

Ortí, F., Pérez-López, A., Salvany, J.-M., 2017. Triassic evaporites of Iberia: Sedimentological and palaeogeographical implications for the western Neotethys evolution during the Middle TriassicEarliest Jurassic. Palaeogeography, Palaeoclimatology, Palaeoecology. https://doi.org/10.1016/j.palaeo.2017.01.025.

Oujidi, M., Courel, L., Benaouiss, N., El Mostaine, M., El Youssi, M., Et Touhami, M., Ouarhache, D., Sabaoui, A., Tourani, A.-I., 2000. Triassic series of Morocco: Stratigraphy, palaeogeography and structuring of the Southwestern Peri-Tethyan Platform. An overview. In: Crasquin-Soleau, S., Barrier, E. (Eds.), Peri-Tethys Memoir 5: New Data on Peri-Tethyan Sedimentary Basins, Mém. mus. natn. Hist. nat, vol. 182, pp. 23-38.

Panfili, G., Cirilli, S., Dal Corso, J., Bertrand, H., Medina, F., Youbi, N., Marzoli, A., 2019. New palynological constraints show rapid emplacement of the Central Atlantic magmatic province during the end-Triassic mass extinction interval. Glob. Planet. Change 172, 60-68.

Papillon, R., 1989. Stratigraphie des Sofs Lias-Dogger des massifs des Senhadja et de l'Azrou Akchar (Rif, Maroc). Publications du Département Géologie et de Paléontologie de I'Université de Genève 8, 217.

Petri, B., Duretz, T., Mohn, G., Schmalholz, S.M., Karner, G.D., Müntener, O., 2019. Thinning mechanisms of heterogeneous continental lithosphere. Earth Planet. Sci. Lett. 512, 147-162.

Piqué, A., Michard, A., 1989. Moroccan Hercynides: a synopsis. The Paleozoic sedimentary and tectonic evolution at the northern margin of West Africa. Am. J. Sci. 289, 286-330.

Rauscher, R., Marhoumi, R., Vanguestaine, M., Hoepffner, C., 1982. Datation palynologique des schistes du Tazekka au Maroc. Hypothèse structural sur le socle hercynien de la Meseta orientale. C.R. Acad. Sc. Paris Série II 294, 1203-1206.

Redfern, J., Shannon, P., Williams, B.P.J., Tyrell, S., Leleu, S., 2010. An integrated study of PermoTriassic basins along the North Atlantic passive margin: implication for future exploration. Petroleum Geology: From Mature Basins to New Frontiers Proceedings of the 7th Petroleum Geology Conf. In: Petroleum Geology Conference Series. Geological Society of London, pp. 921-936. 
Remaci-Benaouda, N., 2005. Pétrologie et géochimie des associations "felsique-mafique" tardihercyniennes oranaises (Algérie Nord occidentale). Implications pétrogénétiques et géodynamiques.. PhD Thesis. Univ. d’Es Senia, Oran, p. 298.

Ricou, L.E., 1994. Tethys reconstructed: Plates continental fragments and their boundaries since 260 Ma from Central America to South-Eastern Asia. Geodin. Acta 7, 169-218.

Rimi, A., 1999. Mantle heat flow and geotherms for the main geologic domains in Morocco. Int. Journ. Earth Sci. 88, 458-466.

Rosenbaum, G., Lister, G.S., Duboz, C., 2002. Relative motions of Africa, Iberia and Europe during Alpine orogeny. Tectonophysics 359, 117-129. https://doi.org/ 10.1016/S0040-1951(02)00442-0.

Sabaoui, A., 1987. Structure et évolution alpine du Moyen Atlas septentrional sur la transversale Tleta du Zerarda-Merhraoua (SW de Taza Maroc). These, Université Toulouse 3.

Saber, H., El Wartiti, M., Hmich, D., Schneider, J.W., 2007. Tectonic evolution from the Hercynian shortening to the Triassic extension in the Paleozoic sediments of the Western High Atlas (Morocco). J. Iberian Geol. 33, 31-40. www.ucm.es/info /estratig/journal.htm.

Saddiqi, O., El Haimer, F.Z., Michard, A., Barbarand, J., Ruiz, G.M.H., Mansour, E.M., Leturmy, P., Frizon de Lamotte, D., 2009. Apatite fissionetrack analyses on basement granites from southewestern Meseta, Morocco: Paleogeographic implications and interpretation of AFT discrepancies. Tectonophysics 475, 29-37.

Sahabi, M., 2004. Evolution cinématique triasico-jurassique de l'Atlantique central: Implications sur l'évolution géodynamique des marges homologues nord ouest africaine et américaine.

Sahabi, M., Aslanian, D., Olivet, J.L., 2004. Un nouveau point de départ pour l'histoire de l'Atlantique central. Compt. Rendus Geosci. 336, 1041-1052.

Sallarès, V., Gailler, A., Gutscher, M.-A., Graindorge, D., Bartolomé, R., Gràcia, E., Díaz, J., Dañobeitia, J.J., Zitellini, N., 2011. Seismic evidence for the presence of Jurassic oceanic crust in the central Gulf of Cadiz (SW Iberian margin). Earth Planet. Sci. Lett. 311, 112-123. https://doi.org/10.1016/i.epsl.2011.09.003.

Salvan, H.M., 1984. Les formations évaporitiques du Trias marocain. Problémes stratigraphiques paléogéographiques et paléoclimatologiques. Quelques reflexions. Rev. Géol. Dyn. Géogr. Phys. 25 (3), 187-203. 
Sani, F., Zizi, M., Bally, A.W., 2000. The Neogene-Quaternary evolution of the Guercif Basin (Morocco) reconstructed from seismic line interpretation. Mar. Pet. Geol. 17 (3), 343-357.

Sani, F., Del Ventisette, C., Montanari, D., Bendkik, A., Chenakeb, M., 2007. Structural evolution of the Rides Prerifaines (Morocco): structural and seismic interpretation and analogue modelling experiments. Int. J. Earth Sci. 96, 685-706.

Saura, E., Verges, J., Martin-Martin, J.D., Messager, G., Moragas, M., Razin, P., Grelaud, C., Joussiaume, R., Malaval, M., Homke, S., Hunt, D.W., 2013. Syn- to post-rift diapirism and minibasins of the Central High Atlas (Morocco): the changing face of a mountain belt. J. Geol. Soc. Lond. 171, 97-105. https://doi.org/10.1144/ jgs2013-079.

Şengör, A.M.C., Burke, K., 1978. Relative timing of rifting and volcanism on Earth and its tectonic implications. Geophys. Res. Lett. 5, 419-421. https://doi.org/10.1029/ GL1005i1006p00419.

Sibuet, J.-C., Rouzo, S., Srivastava, S., 2012. Plate tectonic reconstructions and paleo-geographic maps of the central and North Atlantic oceans. Can. J. Earth Sci. 49, 1395-1415.

Simancas, J.F., Azor, A., Martínez-Poyatos, D., Tahiri, A., El Hadi, H., González- Lodeiro, F., Pérez-Estaún, A., Carbonell, R., 2009. Tectonic relationships of Southwest Iberia with the allochthons of Northwest Iberia and the Moroccan Variscides. Compt. Rendus Geosci. 341, 103-113.

Soua, M., Echihi, O., Herkat, M., Zaghbib-Turki, D., Smaoui, J., Jemia, H.F.B., Belghaji, H., 2009. Structural context of the paleogeography of the Cenomanian- Turonian anoxic event in the eastern Atlas basins of the Maghreb. Compt. Rendus Geosci. 341 (12), 1029-1037.

Soulaimani, A., Essaifi, A., Youbi, N., Hafid, A., 2004. Les marqueurs structuraux et magmatiques de l'extension crustale au Protérozoïque terminal-Cambrien basal autour du massif de Kerdous (Anti-Atlas occidental, Maroc). Compt. Rendus Geosci. 336, 1433-1441.

Stampfli, G.M., 2000. Tethyan oceans. In: Bozkurt, E., Winchester, J.A., Piper, J.D.A. (Eds.), Tectonics and Magmatism in Turkey and the Surrounding Area. Geological Society of London, London, pp. 1-23.

Stampfli, G.M., Borel, G.D., 2004. The TRANSMED transects in space and time: Constraints on the Paleotectonic evolution of the Mediterranean Domain. In: Cavazza, W., Roure, F., Spakman, W., Stampfli, G.M., Ziegler, P. (Eds.), The TRANSMED Atlas: The Mediterranean Region from Crust to Mantle. Springer Verlag, Germany, pp. 53-80.

Stampfli, G.M., Marcoux, J., Baud, A., 1991. Tethyan margins in space and time. In: Channell, J.E.T., Winterer, E.L., Jansa, L.F. (Eds.), Palaeogeography, Palaeoclimatology, Palaeoecology, 87, pp. 373-409. 
Stampfli, G.M., Mosar, J., Favre, P., Pillevuit, A., Vannay, J.-C., 2001. Permo-Mesozoic evolution of the western Tethys realm: the NeoTethys East-Mediterranean Basin connection. In: Ziegler, P.A., Cavazza, W., Robertson, A.H.F., Crasquin-Soleau, S. (Eds.), PeriTethyan Rift/Wrench Basins and Passive margins: National Museum of Natural History, Paris, Memoir n.186, pp. 51-108.

Steckler, M.S., ten Brink, U.S., 1986. Lithospheric strength variations as a control on new plate boundaries: examples from the northern Red Sea region. Earth Planet. Sci. Lett. 79 (1-2), 120-132. https://doi.org/10.1016/0012-821X(86)90045-2.

Suter, G., 1965. La région du Moyen Ouen-ha (Rif, Maroc). Etude préliminaire sur la stratigraphie et la tectonique. Notes Mém. Serv. Géol. Maroc 183, 7-17.

Suter, G., 1980. Carte geologique de la chaine rifaine a 1/500 000. Notes et Mdm. Serv. geol. Maroc, $\mathrm{n}^{\circ} 245 \mathrm{a}$.

Taki, Z., 2012. Styles structuraux du front nord du haut atlas et ces bassins d'avant pays. These. Université IBN Tofail-Kenitra, p. 234.

Teixell, A., Arboleya, M.-L., Julivert, M., Charroud, M., 2003. Tectonic shortening and topography in the central High Atlas (Morocco). Tectonics 22 (1051). https://doi. org/10.1029/2002TC001460.

Teixell, A., Barnolas, A., Rosales, I., Arboleya, M.L., 2017. Structural and facies architecture of a diapirrelated carbonate minibasin (lower and middle Jurassic, High Atlas, Morocco). Mar. Petrol. Geol. 81, $334-360$.

Troudi, H., Tari, G., Alouani, W., Cantarella, G., 2017. Chapter 25 - Styles of Salt Tectonics in Central Tunisia: An Overview. In: Soto, J.I., Flinch, J.F., G. B. T.-P.-T. S. P. of E. Tari (Eds.), North Africa and the Atlantic Margins, Pp. 543-561. Elsevier. https://doi.org/10.1016/B978-0-12-809417-4.00026-4.

Vacherat, A., Mouthereau, F., Pik, R., Bernet, M., Gautheron, C., Masini, E., Le Pourhiet, L., Tibari, B., Lahfid, A., 2014. Thermal imprint of rift-related processes in orogens as recorded in the Pyrenees. Earth Planet. Sci. Lett. 408, 296-306. https:// doi.org/10.1016/j.epsl.2014.10.014.

van Wijk, J.W., Cloetingh, S.A.P.L., 2002. Basin migration caused by slow lithospheric extension. Earth Planet. Sci. Lett. 198, 275-288.

Verati, C., Rapaille, C., Féraud, G., Marzoli, A., Bertrand, H., Youbi, N., 2007. 40Ar/39Ar ages and duration of the Central Atlantic Magmatic Province volcanism in Morocco and Portugal and its relation to the Triassic-Jurassic boundary. Palaeogeogr. Palaeoclimatol. Palaeoecol. 244 (1), 308-325. https://doi.org/10.1016/j. palaeo.2006.06.033. 
Vially, R., Letouzey, J., Benard, F., Haddadi, N., Deforges, G., Askri, H., Boudjema, A., 1994. Basin inversion along the North African margin, the Sahara Atlas (Algeria). In: Roure, F. (Ed.), Peri-Tethyan Platforms. Technip, Paris, pp. 79-118.

Wendt, J., 1985. Desintegration of the continental margin of northwestern Gondwana; late Devonian of the eastern Anti-Atlas (Moroco). Geology 13, 815-818.

Wendt, J., Aigner, T., 1985. Fades patterns and depositional environments of Palaeozoic cephalopod limestones. Sedimentary Geology 44, 263-300.

Wendt, J., Kaufmann, B., Belka, Z., Klug, C., Lubeseder, S., 2006. Sedimentary evolution of a Palaeozoic basin and ridge system: the Middle and Upper Devonian of the Ahnet and Mouydir (Algerian Sahara). Geol. Mag. 143 (3), 269-299. https://doi.org/ 10.1017/s0016756806001737.

Wernert, P., Schulmann, K., Chopin, F., `Stípsk'a, P., Bosch, D., El Houicha, M., 2016. Tectonometamorphic evolution of an intracontinental orogeny inferred from P-T-t-d paths of the metapelites from the Rehamna massif (Morocco). J. Metamorphic Geol. 34, 917-940.

Wigger, P., 1992. Crustal structure along a transverse across the Middle and High Atlas Mountains derived from seismic refraction studies. Geol. Rundsch. 81 (1), 237-248.

Wildi, W., 1983. La chaîne tello-rifaine (Algérie, Maroc, Tunisie): structure, stratigraphie et évolution du Trias du Miocène. Revue Géologie Dynamique et Géolographie Physique 24, 201-297.

Yelles-Chaouche, A.K., Ait-Ouali, R., Bracene, R., Derder, M.E.M., Djelit, H., 2001. Chronologie de l'ouverture du bassin des Ksour (Atlas Saharien, Algérie) au début du Mésozoïque. Rev. Bull. Soc. Géol. Fr. 172, 285-293.

Youbi, N., Martins, L.T., Munhá, J.M., Ibouh, H., Madeira, J., Ait Chayeb, H., El Boukhari, A., 2003. The late Triassic-early Jurassic Volcanism of Morocco and Portugal in the framework of the Central Atlantic Magmatic province: An overview. In: Hames, W.E., MacHone, J.G., Renne, P.R., Ruppel, C. (Eds.), The Central Atlantic Magmatic Province: Insights from Fragments of Pangea, Geophysical Monograph Series, vol. 136. American Geophysical Union, pp. 179-207.

Zahraoui, M., 1994. Le Dévonien inférieur et moyen. In: El Hassani, A., Piqué, A., Tahiri, A. (Eds.), Le Massif central marocain et la Meseta orientale, Bull. Inst. Sci. Rabat, vol. spec, 18, pp. 43-56.

Ziegler, E.A., 1992. European Cenozoic rift system. Tectonophysics 209, 91-111. Ziegler, P.A., Cloetingh, S., 2004. Dynamic processes controlling evolution of rifted basins. Earth Sci. Rev. 64, 1-50. 
Zizi, M., 1996. Triassic-Jurassic Extensional Systems and their Neogene reactivation in Northern Morocco (The Rides Prerifaines and Guercif Basin). PhD thesis. Rice University, Houston.

Zizi, M., 2002. Triassic-Jurassic extensional systems and their Neogene reactivation in Northern Morocco: the Rides Prerifaines and Guercif Basin. In: Notes et Mémoires du Service Géologique, № 416.

Zouaghi, T., Bédir, M., Inoubli, M.H., 2005. 2D interpretation of strike-slip faulting, salt tectonics, and cretaceous unconformities, Atlas Mountains, Central Tunisia. J. Afr. Earth Sci. 43, 464-486. 